\title{
Espécies novas de Anthrenoides Ducke (Hymenoptera, Andrenidae) do Brasil ${ }^{1}$
}

\author{
Danúncia Urban ${ }^{2}$
}

${ }^{1}$ Contribuição n ${ }^{\circ} 1505$ do Departamento de Zoologia, Universidade Federal do Paraná.

${ }^{2}$ Departamento de Zoologia, Universidade Federal do Paraná. Caixa Postal 19020, 81531-980 Curitiba-PR, Brasil. Bolsista do CNPq.

\begin{abstract}
New species of Anthrenoides Ducke (Hymenoptera, Andrenidae) from Brazil. Twenty seven new species of Anthrenoides Ducke, 1907 are described and illustrated: Anthrenoides admirabilis sp. nov., A. albinoi sp. nov., A. antonii sp. nov., A. araucariae sp. nov., A. corrugatus sp. nov., A. cyphomandrae sp. nov., A. densopunctatus sp. nov., A. elegantulus sp. nov., A. faviziae sp. nov., A. guarapuavae sp. nov., A. guttulatus sp. nov., A. langei sp. nov., A. larocai sp. nov., A. magaliae sp. nov., A. meloi sp. nov., A. ornatus sp. nov., A. palmeirae sp. nov., A. paolae sp. nov., A. paranaensis sp. nov., A. petuniae sp. nov., A. pinhalensis sp. nov., A. politus sp. nov., A. reticulatus sp. nov., $A$. rodrigoi sp. nov., A. santiagoi sp. nov., A. serranicola sp. nov. and A. zanellai sp. nov. Main characters of Anthrenoides meridionalis (Schrottky, 1906) and of A. micans Urban, 1995, together with figures, are also presented to allow comparison with the new species. A key for the identification of the species is added.
\end{abstract}

Keywords. Andrenidae; Anthrenoides; Hymenoptera; new species; Panurginae; Taxonomy.

Resumo. Espécies novas de Anthrenoides Ducke (Hymenoptera, Andrenidae) do Brasil. São descritas e ilustradas vinte e sete espécies novas de Anthrenoides Ducke, 1907: Anthrenoides admirabilis sp. nov., A. albinoi sp. nov., A. antonii sp. nov., A. araucariae sp. nov., A. corrugatus sp. nov., A. cyphomandrae sp. nov., A. densopunctatus sp. nov., $A$. elegantulus sp. nov., A. faviziae sp. nov., A. guarapuavae sp.nov., A.guttulatus sp. nov., A. langei sp. nov., A. larocai sp. nov., $A$. magaliae sp. nov., $A$. meloi sp. nov., A. ornatus sp. nov., A. palmeirae sp. nov., A. paolae sp. nov., $A$. paranaensis sp. nov., A. petuniae sp. nov., A. pinhalensis sp. nov., A. politus sp. nov., A. reticulatus sp. nov., $A$. rodrigoi sp. nov., A. santiagoi sp. nov., A. serranicola $\mathbf{s p . ~ n o v . ~ e ~ A . ~ z a n e l l a i ~ s p . ~ n o v . ~ E ́ ~ p r o p o s t a , ~ t a m b e ́ m , ~ u m a ~ c h a v e ~}$ para a identificação das espécies e são apresentadas notas para A. meridionalis (Schrottky, 1906) e A. micans Urban, 1995.

Palavras-Chave. Andrenidae; Anthrenoides; espécies novas; Hymenoptera; Panurginae; Taxonomia.

O gênero Anthrenoides foi proposto por Ducke (1907) para um novo Panurginae coletado em Barbacena, Minas Gerais, A. alfkeni. No ano seguinte, estudando abelhas da Serra de Baturité, Ceará, Ducke (1908) alocou A. alfkeni na sinonímia de Protandrena meridionalis Schrottky, 1906. Michener (2000), incluiu o gênero na chave para os Protandrenini, comentando sua ocorrência no Brasil (São Paulo), até o Paraguai, Argentina (Buenos Aires) e provavelmente no Chile. Silveira et al. (2002) relacionaram três espécies conhecidas do Brasil, A. meridionalis (Schrottky, 1906) descrita do Paraguai, A. alfkeni Ducke, 1907 e A. micans Urban, 1995, do Rio Grande do Sul.

Os Anthrenoides são Protandrenini com três células submarginais nas asas anteriores; fóveas tentoriais na junção das suturas epistomal e subantenais externas; placa labral lisa ou ornada com rúgulas; clípeo pouco elevado a protuberante, com projeções látero-apicais; área mediana das paroculares geralmente deprimida; pronoto sem carena dorsal, apenas com uma elevação do tegumento; os tergos sem máculas amarelas discais. Os machos têm os seguintes caracteres: mandíbulas com a ponta ligeiramente espatulada ou pontiaguda, sem dente subapical; esporões mesotibiais serrilhados; o sétimo tergo arqueado para baixo, sem placa pigidial mas com área mediana brilhante desprovida de pêlos e pilosidade inclinada para o meio; sexto esterno com um recorte mediano largo e muito longo, em forma de "U", como na figura 32, deixando uma área médio-basal muito estreita e ornada com carena subapical ou com carenas laterais convergentes para a base, contínuas com as margens do recorte. As fêmeas têm a face ventral dos mesepisternos revestida com cerdas semi-eretas arqueadas, onduladas ou com as pontas dobradas em forma de gancho; os esporões mesotibiais longos, maiores que a metade do comprimento dos basitarsos, com espinhos ou raramente inermes.

A maioria das espécies descritas a seguir foi coletada no sul do Brasil. O material-tipo está depositado na Coleção de Entomologia Pe. J. S. Moure, Universidade Federal do Paraná, Curitiba (DZUP) e Coleção particular Prof. Rudolf B. Lange (Lange), Curitiba, Paraná. As medidas relacionadas nas descrições são as comumente usadas em abelhas e são dadas em milímetros, o comprimento da asa anterior foi obtido a partir do esclerito costal e a altura da cabeça, do vértice à ponta do clípeo; o termo polido corresponde ao tegumento liso, sem micro-reticulação.

\section{Anthrenoides admirabilis sp. nov.}

(Figs. 1, 22, 26)

Diagnose. Tanto o macho como a fêmea com faixa marginal opaca amarelada, larga e fosca nos tergos a glossa 
extremamente longa, quase igualando o comprimento do corpo; clípeo protuberante, em vista de perfil mais largo que as genas. Macho com labro enegrecido, clípeo amarelo com mácula basal preta e máculas paroculares amarelas de aspecto triangular. Fêmea com cerdas longas e arqueadas na face ventral dos mesepisternos.

Holótipo macho. Comprimento aproximado 10,30; comprimento da asa 6,70; largura da cabeça 3,16 ; altura da cabeça 2,42; comprimento do olho 1,68; comprimento da glossa 10,30 (arqueada). Tegumento predominante preto, labro castanho-enegrecido; clípeo amarelo com mácula preta bilobada nas proximidades do ramo transversal da sutura epistomal, duas nódoas castanhas próximas às fóveas tentoriais e o contorno preto menos o bordo castanho na área protuberante; máculas paroculares amarelas quase triangulares, curtíssimas junto à sutura subantenal externa e longas junto às órbitas. Antenas pretas dorsalmente e com o lado ventral castanho a partir do quarto flagelômero; tégulas translúcidas castanho-enegrecidas; asas méleas, um pouco enegrecidas na ponta, veias, prestigma e pterostigma méleos; esporões mesotibiais castanho-enegrecidos. Tergos pretos, do segundo ao sexto com faixa marginal opaca, amarelada, tão larga como o dobro do diâmetro dos ocelos, e discalmente com estria muito fina amarelo-alaranjada; no tergo basal a faixa marginal obscura e o tergo distal de um castanho-pálido; esternos castanhos com estria bissinuosa amareloacastanhada discal e faixa marginal translúcida esbranquiçada.

Placa labral fracamente trapezoidal e sem rúgulas, inflada látero-basalmente e com a ponta emarginada, as carenas laterais ocupando o terço distal; clípeo polido, com pontos bem marcados e micro-reticulação irregular no terço basal; supraclipeal micro-reticulada e brilhante com pontos esparsos no meio e densos dos lados; carena frontal fina e tão longa como a área supraclipeal; fóveas faciais em forma de clava estreita, menores que $1 / 5$ do comprimento dos olhos $(0,30$ : $1,68)$, com pontos pilígeros na parte dorsal; genas com o contorno ventral obtuso. Mesoscuto e escutelo polidos, o mesoscuto denso-pontuado, os espaços menores que os pontos, escutelo com os pontos pouco maiores que os do mesoscuto porém deixando áreas lisas no disco; depressão basal do propódeo igualando o comprimento do metanoto, com trabéculas separando alvéolos alongados, o rebordo posterior elevado; mesepisternos micro-reticulados; tergo basal com pontos esparsos nas proximidades da área côncava e um pouco densos no restante; segundo e terceiro tergos micro-reticulados na base, com a pontuação um pouco mais densa do que na parte distal do primeiro, a faixa marginal microreticulada e fosca; sexto esterno com carena basal em arco, alongado para a base, contínua com as margens laterais do recorte em "U".

Pilosidade branca e curta, sexto tergo com franja subapical de cerdas lisas decumbentes.

Fêmea. Comprimento aproximado 12,12; comprimento da asa 8,19; largura da cabeça 3,24; comprimento da cabeça 2,84; comprimento do olho 1,87; comprimento da glossa 10,96. Tegumento preto inclusive na cabeça. Antenas, tégulas, asas, pernas e tergos como no macho, do segundo ao quarto tergo com faixa marginal opaca e amarelada, o quinto tergo com faixa marginal translúcida ligeiramente acastanhada, sexto tergo castanho. Esporões mesotibiais castanho-enegrecidos.

Placa labral fracamente trapezoidal com áreas látero-basais infladas e carenas laterais até o meio, com rúgulas na metade basal, um pouco divergentes para os lados e uma rúgula longitudinal mediana; clípeo e carena frontal como no macho; supraclipeal micro-reticulada, com pontuação densa nos lados e área sem pontos estreita junto à carena frontal; fóveas faciais brilhantes, pouco mais curtas que a metade do comprimento dos olhos $(0,85: 1,87)$, mais largas sub-dorsalmente, a ponta estreita e voltada para a fronte, com pontos pilígeros na metade dorsal; mesoscuto, escutelo e base do propódeo como no macho; esporões mesotibiais com 8 espinhos; segundo ao quinto tergo com pontuação muito densa.

Pilosidade branca e pouco conspícua, nos basitarsos anteriores inteiramente castanha, nos medianos castanha na face dorsal e creme na ventral e, nos basitarsos posteriores branca na face dorsal, creme na face ventral e com cerdas enegrecidas na margem anterior; tíbias posteriores com cerdas longas brancas; mesepisternos com cerdas longas arqueadas em direção ao discrímen, deixando medianamente uma pequena área com cerdas muito curtas.

Holótipo macho. BRASIL. Rio Grande do Sul: "São Francisco de / Paula, Pró-Mata, RS / Brasil 15.02.1998 / leg. Birgit Harter" (DZUP). Parátipos com os mesmos dados do holótipo, 2 fêmeas; da mesma localidade, 21.II.1998, Birgit Harter leg., 1 macho e 2 fêmeas; Paraná: [Tunas do Paraná / Cerro Azul] Parque Estadual de Campinhos, 22.XI.2003, R. Gonçalves \& F. Fernandes leg., 2 fêmeas. Todos no DZUP.

Comentários. O alongamento extraordinário da glossa, a protuberância do clípeo e as faixas opacas amareladas dos tergos são únicos entre os Anthrenoides descritos neste trabalho. O parátipo macho tem as máculas paroculares mais curtas junto ao clípeo, não alcançando a sutura subantenal externa e o clípeo com o rebordo preto alargado junto aos ramos laterais da sutura epistomal.

\section{Anthrenoides albinoi sp. nov.}

(Fig. 2)

Diagnose. Macho com placa labral castanho-enegrecida, ornada com dois tubérculos espiniformes no ápice; clípeo amarelo com duas máculas castanho-enegrecidas no disco; depressão basal do propódeo estreita e com alvéolos. Fêmea com a glossa curta, pouco maior que a metade do comprimento do olho; mesepisternos com pontos como os do mesoscuto, porém mais esparsos; tergos quase foscos; depressão basal do propódeo curta e alveolada.

Holótipo macho. Comprimento aproximado 10,83; comprimento da asa anterior 8,12 ; largura da cabeça 2,88; altura 
da cabeça 2,18; comprimento do olho 1,52. Cabeça e mesossoma castanho-enegrecidos, exceto o clípeo e as máculas paroculares amarelos, o clípeo com a margem, incluindo as projeções láteroapicais digitiformes e as duas máculas discais castanhoenegrecidas, as máculas mais longas que o dobro do ocelo mediano e unidas ao ramo horizontal da sutura epistomal por pequena área castanho-pálida; máculas paroculares curtas e muito estreitas medialmente, não alcançando a sutura subantenal externa; pernas castanhas, esporão mesotibial esbranquiçado; tégulas translúcidas castanho-amareladas na ponta e enegrecidas na metade basal; asas tingidas de amareloméleo na base e de amarelo-acastanhado no restante; tergos castanho-amarelados, esternos um pouco mais amarelados que os tergos.

Placa labral muito larga na base, onde é pouco distinta do restante do labro, sem carena apical e sem carenas laterais, somente com dois tubérculos espiniformes no ápice; clípeo polido com pontos grandes esparsos e projeções látero-apicais digitiformes; fronte sem carena; fóveas faciais elipsóides, largas e curtas, medindo um pouco mais que $1 / 4$ do comprimento do olho $(0,42: 1,52)$; genas com angulosidade ventral obtusa; mesoscuto e escutelo polidos, o mesoscuto com pontuação densa, os pontos separados por espaços de 1 a 3 diâmetros de ponto, no escutelo os pontos maiores e mais esparsos; depressão basal do propódeo mais curta que o metanoto, com alvéolos alongados separados por trabéculas e com o rebordo posterior elevado; mesepisternos micro-reticulados com pontos como os do clípeo, separados por 2 a 3 diâmetros de ponto; tergo basal com pontos finos pouco densos, nos dois seguintes mais densa e o tegumento micro-reticulado; faixa marginal dos tergos quase fosca, micro-reticulada; sexto esterno com as carenas laterais convergentes para a base.

Pilosidade branca, curtíssima em grande parte da cabeça, mesoscuto e parte dorsal dos mesepisternos; castanho-pálida no tergo distal; sexto tergo com franja rala de pêlos decumbentes finos e longos.

Fêmea. Comprimento aproximado 11,61; comprimento da asa anterior 8,42; largura da cabeça 2,94; altura da cabeça 2,35; comprimento do olho 1,70. Tegumento preto com uma tonalidade acastanhada nas pernas; tégulas translúcidas castanho-amareladas na ponta e enegrecidas na metade basal; asas tingidas de castanho-amarelado; esporão mesotibial castanho-enegrecido; tergos com faixa marginal fosca levemente brônzea; esternos com orla amarelo-palha.

Placa labral fracamente trapezoidal um pouco deprimida distalmente, uma rúgula médio-discal fraca, base quase lisa, com as carenas laterais até o meio, fracas; clípeo polido com pontos grandes separados por espaços irregulares; supraclipeal polida, com pontos pouco maiores e esparsos junto ao clípeo e no disco, porém nos lados menores e muito densos; fronte abaulada e sem carena, com sulco curto pontilhado e fundo; fóveas faciais largas e longas, mais largas que o escapo e quase igualando a metade do comprimento dos olhos $(0,86$ : 1,70); mesoscuto e escutelo polidos, o mesoscuto denso-pontuado, os intervalos muito pequenos ou igualando o tamanho dos pontos; no escutelo os pontos com o dobro do tamanho dos pontos mesoscutais, densos porém deixando intervalos do tamanho dos pontos; depressão basal do propódeo mais estreita que a metade do metanoto e distintamente alveolada; mesepisternos micro-reticulados e foscos com pontos grandes como os mesoscutais, separados por intervalos de 1 a 3 diâmetros de ponto; esporão mesotibial com 8 espinhos; tergos denso-pontuados com faixa marginal quase fosca, densamente micro-reticulada.

Pilosidade levemente amarelada, curtíssima no mesoscuto e nos tergos basais, porém nos dois distais castanho-pálida e longa; tíbias posteriores com cerdas castanhas; cerdas ventrais dos mesepisternos longas e levemente arqueadas.

Holótipo macho. BRASIL. Rio de Janeiro: "Brasil Rio de Janeiro / D[istrito]. F[ederal]. Corcovado / 19 outubro 1957 / Seabra e Alvarenga"; "Coleção / Campos Seabra" (DZUP). Parátipos. Rio de Janeiro, Rio de Janeiro, Floresta da Tijuca, 12.XII.1955, C. A. C. Seabra leg., 1 fêmea; Tijuca 500m, 15.XI.1955, Moure \& Seabra leg., 2 fêmeas; Santa Catarina: Joinville, 13.XII.1988, A. A. Soares leg., 1 fêmea. Todos no DZUP.

Comentário. No macho, chamam a atenção os tubérculos apicais espiniformes da placa labral e as máculas castanhas do clípeo. A fêmea com os tergos foscos e com o mesmo padrão de colorido de $A$. langei $\mathbf{s p . ~ n o v . ~ e ~} A$. densopunctatus sp. nov.; porém estas duas espécies têm micro-reticulação no clípeo, mesoscuto e no escutelo e os mesepisternos com pontuação fina e esparsa, os pontos pouco maiores que os retículos e rasos.

Espécie dedicada ao Prof. Dr. Albino Morimasa Sakakibara, Departamento de Zoologia, UFPR.

\section{Anthrenoides antonii sp. nov.}

(Fig. 3)

Diagnose. Mesoscuto e escutelo polidos, tergos basais com pontuação escassa. Macho com a placa labral, clípeo e paroculares inferiores esbranquiçados, máculas paroculares em forma de gota e quase tão longas como o clípeo, sem carena frontal e com os mesepisternos polidos. Fêmea com os mesepisternos brilhantes e com micro-reticulação muito fraca, superficial.

Holótipo macho. Comprimento aproximado 8,17; comprimento da asa 5,53; largura da cabeça 2,18; altura da cabeça 1,56 ; comprimento do olho 1,10 . Tegumento preto na cabeça e dorso do mesossoma; genas e face ventral do mesossoma castanho-enegrecidos; esbranquiçado na placa labral, clípeo e paroculares inferiores, o clípeo com orla e duas nódoas pretas junto às fóveas tentoriais, as paroculares com a mácula até o terço inferior da sutura subantenal externa e um pouco mais longa junto aos olhos; antenas castanhas, mais escuras dorsalmente; tégulas castanhas, translúcidas; asas tingidas de amarelo-acastanhado; pernas castanho-escuras, as tíbias anteriores com mácula alongada amarelo-âmbar na face ventral e pequena nódoa basal amarela na face externa, as 
medianas também com nódoa amarela basal; esporões mesotibiais esbranquiçados. Tergos e esternos castanhoenegrecidos com faixa marginal translúcida castanha, o tergo distal castanho-claro.

Placa labral retangular estreita com carenas laterais só junto ao ápice, delimitada por angulosidades; clípeo polido, sem carena mediana, com pontos esparsos; área supraclipeal inflada, polida e com pontos esparsos nos lados; fronte elevada medialmente com sulco interalveolar fino e curto, orlado com carenas finíssimas; fóveas faciais curtas e estreitas, quase igualando $1 / 4$ do comprimento dos olhos $(0,24: 1,10)$; genas com angulosidade ventral obtusa; mesoscuto e escutelo polidos, com pontos irregularmente distribuídos, finos e esparsos, deixando grandes áreas lisas, mais densos ao redor do mesoscuto; mesepisternos polidos; depressão basal do propódeo tão longa como o metanoto, brilhante e com microreticulação rasa, porém com o rebordo posterior sem microreticulação e fracamente delimitado; tergos basais com pontos muito finos e áreas lisas grandes, quase igualando o tamanho dos ocelos, faixa marginal larga e brilhante, com microreticulação fraca em todos os tergos; sexto esterno com carena basal em arco, contínua com as margens laterais do mesmo.

Pilosidade predominante branca, porém na face ventral dos basitarsos amarelo-âmbar; depressão basal do propódeo sem pêlos; tergos quase glabros, do segundo ao quarto com pequenas faixas laterais, quinto e sexto com franja decumbente longa e esparsa; tergo distal com pêlos castanhos pálidos.

Fêmea. Comprimento aproximado 10,57; comprimento da asa 6,08; largura da cabeça 2,53; altura da cabeça 1,83 ; comprimento do olho 1,24 . Tegumento da cabeça castanhoavermelhado, mais claro nas genas; antenas castanhas dorsalmente; mesoscuto e escutelo pretos, demais partes do mesossoma de um castanho-avermelhado; asas levemente tingidas de ferrugíneo; tíbias anteriores e medianas com nódoa basal amarela; esporões mesotibiais castanho-claros; tergos e esternos castanho-avermelhados com faixa marginal translúcida amarelada.

Placa labral sem rúgulas, retangular, arredondada nos cantos, delimitada por carenas nos $2 / 3$ distais; clípeo polido e sem carena, com pontos grandes; supraclipeal polida, elevada e com pontos esparsos, densos somente junto às suturas subantenais; fronte com sulco fino, como no macho, prolongado dorsalmente em carena finíssima; fóveas faciais largas porém estreitando um pouco ventralmente, igualando um terço do comprimento dos olhos $(0,40: 1,24)$; mesoscuto e escutelo polidos com pontos esparsos de tamanhos diferentes, mais densos ao redor dos escleritos; esporões mesotibiais com três espinhos fortes; mesepisternos brilhantes, com microreticulação fraquíssima; depressão basal do propódeo sem rúgulas; tergos como no macho.

Pilosidade branca predominando, creme-amarelada na face ventral dos basitarsos; face ventral dos mesepisternos com cerdas onduladas; tíbias posteriores com cerdas brancas na face dorsal; sem pêlos na depressão basal do propódeo; tergos com pêlos brancos muito curtos, no quinto castanhos claros.
Holótipo macho. BRASIL. Paraná: "Brasil, Piraquara, PR, / Mananciais da Serra / 03.XI.2002 / AJC Aguiar / G. Melo \& I. AlvesSantos" (DZUP). Parátipos. Paraná: Curitiba, 25.I.1964, N. L. Marston leg., 1 macho; da mesma localidade, X.1944, sem indicação do coletor, 1 macho; Curitiba (Barigui), X.1944, R. Lange leg., 3 machos e 2 fêmeas; [Morretes] Volta Grande, XII.1943, R. Hertel leg., 1 fêmea; Piraquara, III.1965, Mitchell \& Moure leg., 1 macho; São José dos Pinhais, III.1963, C. Elias leg., 1 fêmea. Rio Grande do Sul: Pto. [Porto] Alegre, 3.XI.1978, A. D. leg., 1 macho e 1 fêmea (DZUP).

Comentário. O macho de $A$. araucariae sp. nov., também tem o mesoscuto, escutelo e os mesepisternos polidos, porém difere por ter a placa labral preta e máculas paroculares em forma de gota alongada.

Espécie em homenagem ao Antonio José Camillo de Aguiar.

\section{Anthrenoides araucariae sp. nov.}

(Fig. 4)

Diagnose. Macho com placa labral preta, clípeo amarelo, paroculares inferiores com mácula amarela em forma de gota alongada; mesoscuto, escutelo e mesepisternos polidos.

Holótipo macho. Comprimento aproximado 9,03; comprimento da asa 6,37; largura da cabeça 3,03; altura da cabeça 2,11; comprimento do olho 1,71. Tegumento preto predominando na cabeça e mesossoma, as genas de um castanho-avermelhado escuro; clípeo amarelo com duas nódoas engrecidas junto às fóveas tentoriais, a margem distal também enegrecida; paroculares inferiores com mácula amarela em forma de gota alongada; asas tingidas de castanho; tíbias sem nódoa amarela basal; esporões mesotibiais castanhoamarelados; tergos castanho-escuros, levemente avermelhados e com faixa marginal larga castanho-amarelada e translúcida; três tergos basais com estria fina amareloalaranjada discal, nos dois seguintes e estria pouco distinta; esternos castanhos com a faixa marginal amarelada.

Placa labral levemente trapezoidal, com angulosidades nos lados e carenas laterais no terço distal; clípeo polido com pontos grandes não densos, os espaços maiores que os pontos e também pontos pequenos esparsos; supraclipeal polida, com área sem pontos no disco, pouco protuberante; fronte com carena baixa na área interalveolar; fóveas faciais mais largas no terço dorsal, brilhantes, mais curtas que $1 / 3$ do comprimento dos olhos $(0,54: 1,71)$; genas com angulosidade ventral obtusa; mesoscuto e escutelo polidos, com pontos separados por espaços irregulares, as áreas sem pontos maiores no disco, escutelo com pontos esparsos; mesepisternos polidos; esporões mesotibiais esbranquiçados; depressão basal do propódeo igualando o comprimento do metanoto, com rúgulas divergentes e micro-esculturação irregular, o contorno posterior um pouco elevado; tergos basais com pontos esparsos na base e no disco, a faixa marginal brilhante e sem micro-reticulação distinta, os demais tergos com pontos um pouco mais densos; sexto esterno com carena basal em arco, contínua com as margens laterais do mesmo.

Pilosidade branca predominando, porém na face ventral dos basitarsos creme-amarelada; nos tergos muito escassa e 
curta, quarto e quinto tergos com franjas subapicais decumbentes e ralas; o sexto tergo com pêlos castanhos pálidos.

Holótipo macho. BRASIL. Paraná: "Araucária, PR / Brasil. 27.IX.87 / D. Renaux leg.” (DZUP). Parátipos. Paraná: Curitiba, X.1944, sem indicação de coletor, 2 machos; Santa Catarina: Nova Teutônia [Seara], X.1950, F. Plaumann leg., 1 macho (DZUP).

Comentário. Mesoscuto, escutelo e mepisternos polidos, como no macho de $A$. antonii sp. nov., que difere pelo porte um pouco menor, por ter a placa labral esbranquiçada e pela depressão basal do propódeo lisa e com micro-reticulação rasa. A estria discal finíssima, amarelo-alaranjada, como a dos tergos de A. admirabilis sp. nov. O parátipo de Nova Teutônia sem o metassoma.

\section{Anthrenoides corrugatus sp. nov.}

(Figs.19, 27)

Diagnose. Fêmea com placa labral trapezoidal alongada e quase lisa, sulco frontal fino e curto entre os alvéolos, fóveas faciais longas e brilhantes, tíbias e basitarsos com pilosidade castanha; face dorsal das tíbias posteriores com cerdas bicoloridas, com a ponta branca e o restante enegrecido, mescladas com cerdas enegrecidas.

Holótipo fêmea. Comprimento aproximado 11,22; comprimento da asa 7,84; largura da cabeça 3,13; altura da cabeça 2,29; comprimento do olho 1,73. Tegumento preto na face e dorso do mesossoma; castanho-escuro levemente avermelhado no vértice, genas, mesepisternos, pernas, margem dos tergos e nos esternos. Antenas enegrecidas com o lado ventral castanho-amarelado a partir do terceiro flagelômero; asas tingidas de castanho, prestigma e pterostigma castanhos; tíbias sem nódoa amarela basal; esporões mesotibiais castanhos; tergos enegrecidos com a faixa marginal castanhopálida larga e translúcida.

Placa labral trapezoidal, mais longa que larga, com vestígios de rúgulas basais e as carenas laterais quase até a base; clípeo polido com pontos minúsculos esparsos e pontos grandes, maiores que o dobro dos mesoscutais; supraclipeal um pouco elevada, polida e com pontuação irregular; fronte com sulco fino interalveolar; fóveas faciais longas e largas, brilhantes, menores que $1 / 3$ do comprimento dos olhos $(0,52: 1,73)$, mais largas sub-dorsalmente; mesoscuto micro-reticulado com pontos irregularmente distribuídos, não densos; escutelo brilhante e com micro-reticulação fraca, os pontos maiores que os do mesoscuto e mais esparsos; esporões mesotibiais com 7 espinhos pequenos e micro-espinhos basais; mesepisternos micro-reticulados; depressão basal do propódeo mais longa que o metanoto, com rúgulas irregulares anastomosadas e micro-esculturação, rebordo posterior um pouco elevado; tergo basal com poucos pontos, polido, segundo e terceiro tergos com pontos muito finos pouco densos, esparsos no disco; faixa marginal dos tergos larga, com lineolado descontínuo.
Pilosidade esbranquiçada; nas tíbias e basitarsos castanha; face dorsal das tíbias posteriores com mescla de cerdas enegrecidas e cerdas com a parte basal enegrecida e a apical branca; face ventral dos mesepisternos com cerdas longas quase eretas, fracamente onduladas; no quinto tergo castanho-enegrecida e no distal castanho-pálida.

Holótipo fêmea. BRASIL. Santa Catarina: “ N. Teutônia, S[anta]. C[atarina]. / II/V-1948 / Fritz Plaumann” (DZUP).

Comentários. A placa labral trapezoidal e as tíbias posteriores com cerdas bicoloridas como em A. cyphomandrae sp. nov.; porém A. corrugatus difere pelo clípeo e supraclipeal polidos e pela depressão basal do propódeo longa e com rúgulas anastomosadas. Anthrenoides meridionalis (Schrottky, 1906), também com cerdas bicoloridas nas tíbias posteriores, difere pelos tergos, com pontuação fina e densa a partir do segundo, os espaços igualando o tamanho dos pontos e pela área supraclipeal sem pontos no disco.

\section{Anthrenoides cyphomandrae sp. nov.}

(Fig. 28)

Diagnose. Fêmea com a placa labral trapezoidal, com rúgulas anastomosadas na base e ultrapassando a metade do comprimento da placa; clípeo e supraclipeal com pontos grandes, rasos e micro-reticulados, brilhantes e com microreticulação rasa e irregular; sulco frontal fino orlado com carenas pontuadas estreitas, fóveas faciais rasas e bem delimitadas, pilosidade enegrecida nas tíbias e basitarsos; as tíbias posteriores com cerdas bicoloridas, enegrecidas na base e brancas na metade distal.

Holótipo fêmea. Comprimento aproximado 11,35; comprimento da asa 7,02; largura da cabeça 2,65; altura da cabeça 2,14; comprimento do olho 1,58. Tegumento da cabeça predominantemente preto, passando a avermelhado nas mandíbulas; antenas de um castanho-escuro ventralmente a partir do terceiro flegelômero; mesossoma enegrecido, com leve tonalidade avermelhada no escutelo, propódeo e pernas; asas tingidas de castanho, prestigma e pterostigma castanhoclaros, o pterostigma amarelado no disco; tíbias sem nódoa amarela basal; esporões mesotibiais enegrecidos; tergos pretos na base, a faixa marginal castanha um pouco translúcida.

Placa labral alongada, trapezoidal, com a largura basal igual ao dobro da apical, delimitada por carenas nos $2 / 3$ látero-apicais, com rúgulas até pouco além da metade do seu comprimento, as rúgulas anastomosadas junto à base, um pouco divergentes para a ponta; clípeo com micro-esculturação rasa e irregular, com pontos grandes e rasos, sem carena mediana; supraclipeal protuberante, com ornamentação como a do clípeo e com pontos rasos na parte mais dorsal; fronte com sulco fino e curto, orlado por elevações muito estreitas; fóveas faciais micro-esculturadas, rasas e bem delimitadas, mais largas no meio e mais longas que $1 / 3$ do comprimento dos olhos $(0,60$ : $1,58)$; mesoscuto e escutelo com micro-reticulação pouco 

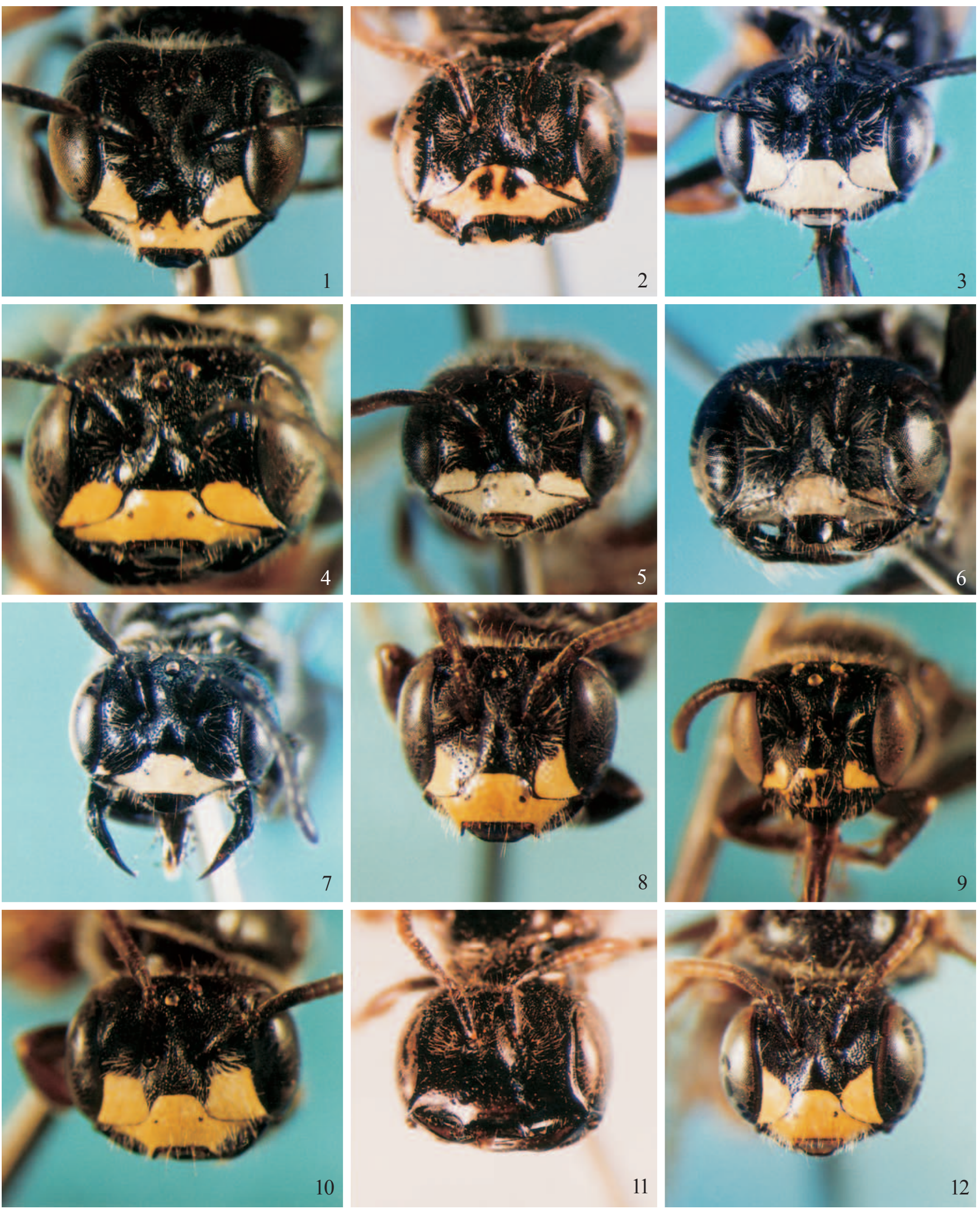

Figs. 1-12. Vista frontal da cabeça dos holótipos de: (1) Anthrenoides admirabilis; (2) A. albinoi; (3) A. antonii; (4) A. araucariae; (5) A. elegantulus; (6) A. faviziae; (7) A. guarapuavae; (8) A. larocai; (9) A. magaliae; (10) A. meloi; (11) A. ornatus; (12) A. palmeirae. Todos machos. 
marcada; mesoscuto com pontos finos e densos, separados por espaços medindo de 1 a 2 diâmetros de ponto; no escutelo os pontos maiores que os do mesoscuto e menos densos; esporões mesotibiais quase tão longos como o basitarso, com 8 espinhos maiores e alguns menores e mais finos para a base; mesepisternos micro-reticulados; depressão basal do propódeo curta, pouco maior que a metade do comprimento do metanoto, com rúgulas quase paralelas e rebordo posterior um pouco elevado; tergo basal com pontos finos escassos; no segundo e terceiro os pontos um pouco menos esparsos.

Pilosidade esbranquiçada; enegrecida nas tíbias e nos basitarsos, porém na face ventral dos basitarsos posteriores creme-amarelada; nas tíbias posteriores com mescla de cerdas enegrecidas e cerdas bicoloridas, enegrecidas na base e com a metade distal branca; nos tergos amarelo-creme, mais densa no quarto, franja do quinto tergo castanho-amarelada.

Holótipo fêmea. BRASIL. Santa Catarina: "Brasilien / Nova Teutonia / 27 $7^{\circ} 11^{\prime} \mathrm{S}-52^{\circ} 23^{\prime}$ / Fritz Plaumann / XI.1957 / 300-500 m” (DZUP); [colado em um cartão]. Parátipo. Paraná: Tijucas do Sul (Vossoroca), 2. XII.1988, A. A. Soares leg., 1 fêmea coletada em Cyphomandra pinetorum L. B. Sm. \& Downs (Solanaceae) (DZUP).

Comentário. Como A. corrugatus sp. nov., tem os três artículos distais dos palpos labiais quase tão longos como o dobro do diâmetro do ocelo médio. O holótipo está colado em um cartão, e o parátipo foi coletado em Cyphomandra pinetorum L. B. Sm. \& Downs (Solanaceae).

\section{Anthrenoides densopunctatus sp. nov.}

(Fig. 20)

Diagnose. Fêmea com a placa labral fracamente trapezoidal e com rúgulas divergentes do meio para os lados, carena frontal fina e longa, fóveas faciais longas e muito rasas, tíbias e os basitarsos anteriores e medianos com pêlos castanhos; as tíbias posteriores com cerdas castanhas na base e esbranquiçadas na ponta e cerdas inteiramente castanhas.

Holótipo fêmea. Comprimento aproximado 8,58; comprimento da asa 7,02; largura da cabeça 2,63; altura da cabeça 2,17; comprimento do olho 1,64. Tegumento preto na cabeça, com uma tonalidade avermelhada nas genas; asas tingidas de amarelo-méleo, prestigma e pterostigma méleos; tíbias sem nódoa amarela basal; esporões mesotibiais castanho-escuros; mesossoma e metassoma enegrecidos com uma tonalidade um pouco avermelhada, nos tergos e esternos a faixa marginal levemente acastanhada.

Placa labral fracamente trapezoidal com depressão subapical e os cantos distais arredondados, delimitada por carenas nos 2/3 látero-apicais, com rúgulas longas divergentes do meio para os lados; clípeo micro-reticulado, com carena mediana fina, pontos rasos e grandes, também microreticulados; supraclipeal um pouco elevada, micro-reticulada e com pontos menores que os clipeais; carena frontal longa e fina, até o ocelo mediano; fóveas faciais muito rasas, apenas perceptíveis pelo brilho diferenciado, largas e maiores que $1 / 3$ do comprimento dos olhos $(0,60: 1,64)$; mesoscuto e escutelo micro-reticulados, mesoscuto com pontuação densa e fina, os intervalos menores que os pontos, o escutelo com os pontos maiores que os do mesoscuto e também densos; esporões mesotibiais quase tão longos como os basitarsos, com 6 espinhos; mesepisternos micro-reticulados; depressão basal do propódeo mais longa que a metade do comprimento do metanoto, com rúgulas paralelas no meio e um pouco divergentes nos lados; tergo basal micro-reticulado e com pontuação muito esparsa, os demais com micro-reticulação densa tanto na faixa marginal como na base.

Pilosidade branca predominando; nas tíbias e basitarsos anteriores e medianos castanha e nas tíbias posteriores com cerdas inteiramente castanhas e cerdas castanhas na base e com a ponta branca; face ventral dos mesepisternos com cerdas finas com as pontas dobradas em forma de gancho; muito curta, densa e decumbente nos tergos, no quarto amarelodourada, e no quinto tergo amarelo-acastanhada.

Holótipo fêmea. BRASIL. Santa Catarina: "Nova Teutonia, / Santa Caterina [sic], Brazil [sic] IX-1951/ L. E. Plaumann” (DZUP).

Comentários. Lembra A. paolae sp. nov., pela microreticulação da cabeça. A. paolae difere por ter a placa labral quadrangular com rúgulas basais fracas, mesoscuto e escutelo foscos porém com pontos muito esparsos e pouco maiores que os retículos. A cabeça do holótipo está colada em um cartão e não tem as antenas.

\section{Anthrenoides elegantulus sp. nov.}

(Fig. 5)

Diagnose. Macho com a placa labral, clípeo e paroculares inferiores esbranquiçados, as máculas paroculares curtas e quase retangulares; genas com um tubérculo pequeno na angulosidade ventral, mesoscuto e escutelo polidos, somente o tergo basal com área médio-discal desprovida de pontos, demais tergos com pontuação fina.

Holótipo macho. Comprimento aproximado 5,61; comprimento da asa 4,46; largura da cabeça 2,01; altura da cabeça 1,40; comprimento do olho 1,02. Preto em parte da face, mesoscuto, escutelo e tergos intermediários; castanhoavermelhado nas genas, vértice, mesossoma e tergos distais; placa labral, clípeo e paroculares inferiores esbranquiçados; o clípeo com duas nódoas castanhas junto às fóveas tentoriais e a margem também castanha; a mácula das paroculares curta, quase retangular; antenas com os artículos basais pretos, castanhas dorsalmente a partir do quarto flagelômero, ventralmente amarelo-ocráceas a partir do segundo; asas tingidas de amarelo-acastanhado, pterostigma amareloacastanhado com o contorno castanho; pernas castanhas; tíbias anteriores e medianas com nódoa amarela basal; esporões mesotibiais esbranquiçados; dois tergos basais castanhoclaros com manchas enegrecidas, terceiro ao quinto tergo com 

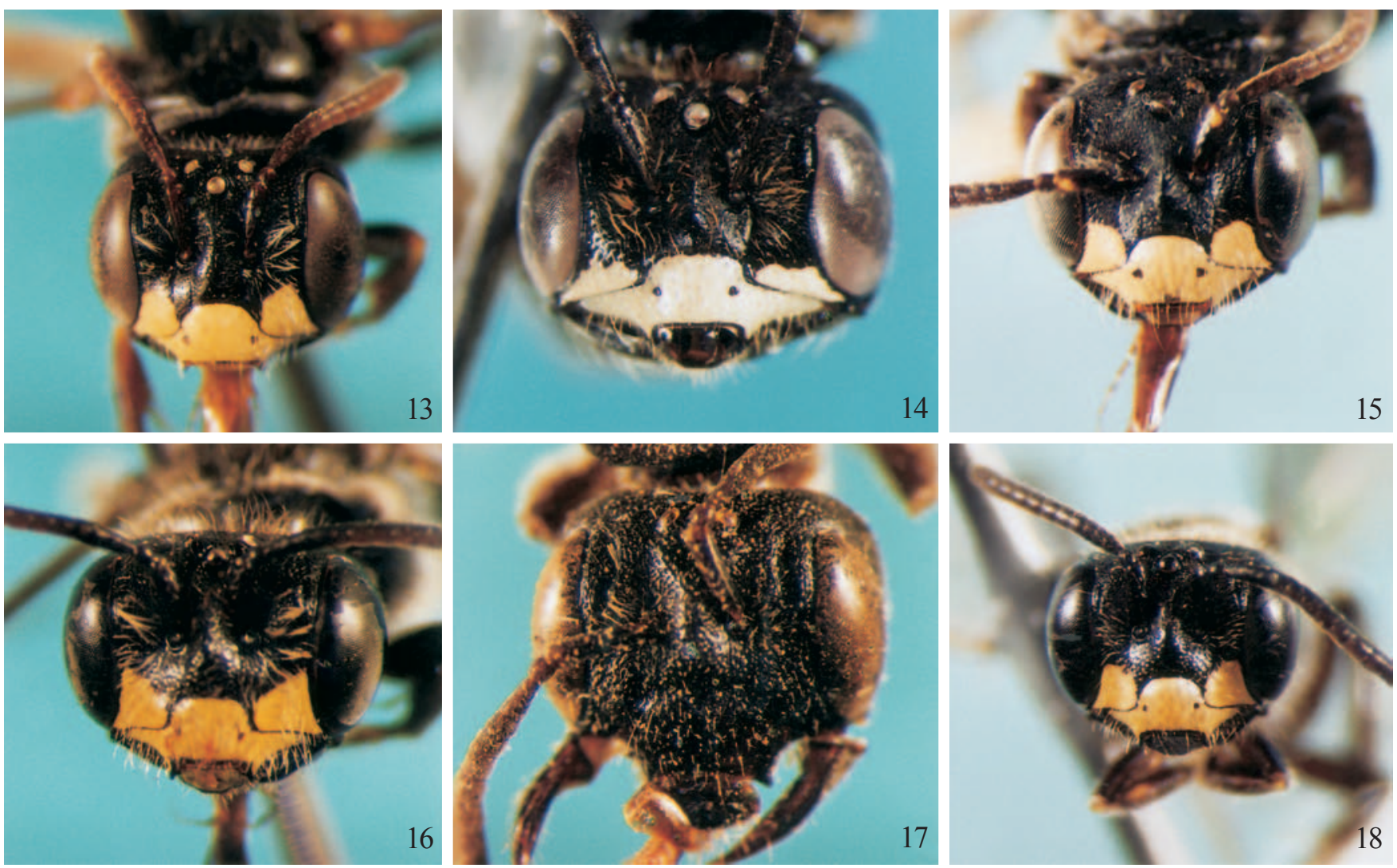

Figs. 13-18. Vista frontal da cabeça. (13) Anthrenoides petuniae; (14) A. pinhalensis; (15) A. reticulatus; (16) A. rodrigoi; (17) A. serranicola; (18) A. meridionalis. Figs. 13 a 17, dos holótipos. Todos machos.

faixa marginal larga, translúcida e amarelo-mélea; esternos castanho-avermelhados com áreas pretas e faixa marginal translúcida amarelada.

Placa labral retangular com carenas laterais junto ao ápice; clípeo polido, sem micro-reticulação, com pontos grandes esparsos e sem carena; supraclipeal polida e protuberante, com pontos aos lados; carena frontal curta e fina; fóveas faciais muito curtas e estreitas, brilhantes, o comprimento igualando 1/5 do comprimento dos olhos $(0,19: 1,02)$; genas com angulosidade ventral pequena projetada em forma de tubérculo; mesoscuto e escutelo polidos com pontos pequenos esparsos, um pouco mais densos ao redor do mesoscuto; mesepisternos micro-reticulados e brilhantes; depressão basal do propódeo tão longa como o metanoto, brilhante, com microreticulação esparsa e área polida na metade distal, o contorno posterior fracamente elevado; tergos com pontuação fina, não densa, exceto o primeiro com pontos esparsos e uma área médio-discal desprovida de pontos; faixa marginal dos tergos irregularmente lineolada, brilhante; sexto esterno com carena basal em arco, contínua com as margens laterais do mesmo.

Pilosidade branca, menos o mesoscuto com pêlos levemente acastanhados e a face ventral dos basitarsos amarelo-âmbar; tergos com pêlos esparsos nas laterais da faixa marginal, os tergos subapicais com franja esparsa e decumbente.
Holótipo macho. BRASIL. Paraná: "S. J. Pinhais-PR / Brasil-III63 / C. Elias leg" (DZUP). Parátipo do Paraná: Colombo, III. 1963, S. Laroca leg., 1 macho (DZUP).

Comentário. Como A. antonii sp. nov., A. faviziae sp. nov. e A. pinhalensis sp. nov., com as máculas cefálicas esbranquiçadas. A. antonii difere de A. elegantulus por ter os mesepisternos polidos; A. faviziae, por ter lóbulo achatado nas genas e rúgulas irregulares divergentes na depressão basal do propódeo, e A. pinhalensis, difere pela depressão basal do propódeo lineolada e micro-reticulada, sem área polida.

\section{Anthrenoides faviziae sp. nov.}

(Figs. 6, 23)

Diagnose. Macho com placa labral preta, clípeo e máculas paroculares inferiores esbranquiçados, cabeça microreticulada, genas com lóbulo ventral carenado e côncavo, carena frontal longa e fóveas faciais rasas.

Holótipo macho. Comprimento aproximado 8,77; comprimento da asa 6,86; largura da cabeça 2,98 , altura da cabeça 1,87; comprimento do olho 1,63. Tegumento predominantemente preto, exceto o clípeo e as máculas das 
paroculares inferiores esbranquiçados, as máculas paroculares curtíssimas junto às fóveas tentoriais; clípeo com duas nódoas castanhas próximas das fóveas tentoriais e a borda castanha; asas tingidas de castanho; pernas e tergos castanhoenegrecidos com leve toque avermelhado; tíbias sem nódoa amarela basal; esporões mesotibiais castanho-escuros; esternos castanho-enegrecidos com áreas castanhoamareladas.

Quase toda a cabeça micro-reticulada e brilhante; placa labral levemente trapezoidal, com carenas laterais na metade distal, emarginada no ápice; clípeo micro-reticulado com pontos grandes e rasos; supraclipeal um pouco elevada, com pontos muito rasos, escassos e irregulares; fronte com carena fina, da tangente alveolar inferior até o ocelo mediano; fóveas faciais apenas delimitadas, muito rasas e mais curtas que $1 / 3$ do comprimento dos olhos $(0,48: 1,63)$; genas com projeção ventral achatada em forma de lóbulo carenado, um pouco côncavo e maior que o ocelo; mesoscuto com fraca microreticulação e pontuação rasa, fina e esparsa; escutelo microreticulado com pontos esparsos porém maiores que os do mesoscuto, áreas sem pontos um pouco menores que o diâmetro do ocelo; mesepisternos micro-reticulados; depressão basal do propódeo quase tão longa como o metanoto, micro-esculturada e brilhante, com poucas rúgulas rasas divergentes do meio para os lados, contorno posterior evidente; tergos brilhantes, pontuação fina e esparsa no basal, um pouco mais densa nos demais, com faixa marginal larga e fracamente lineolada; sexto esterno com carenas basais convergentes, separadas por área muito pequena, o tegumento entre as carenas quase triangular.

Pilosidade esparsa branca e creme; na face ventral dos basitarsos amarelo-âmbar; quinto e sexto tergos com franja branca esparsa e decumbente, no tergo distal castanho-pálida.

Holótipo macho. BRASIL. Paraná: “ S. José Pinhais - PR / Brasil (Br 277 km 54) 17-24-VI.1985 / C. I. I. F. (Malaise)" (DZUP).

Comentário. Como A. pinhalensis sp. nov. e $A$. guarapuavae sp. nov., o macho tem a placa labral preta e máculas faciais esbranquiçadas; porém $A$. pínhalensis tem um tubérculo pequeno nas genas e $A$. guarapuavae tem as genas angulosas além das paroculares um pouco abauladas no meio. O holótipo está com as máculas cefálicas em parte translúcidas possivelmente por ter permanecido longo tempo em álcool antes de ter sido montado.

Espécie em homenagem à Favízia Freitas de Oliveira.

\section{Anthrenoides guarapuavae sp. nov.}

$$
\text { (Fig. 7) }
$$

Diagnose. Macho com a placa labral preta, clípeo e nódoas paroculares esbranquiçados; mesoscuto e escutelo polidos, genas sem tubérculo ventral; as paroculares um pouco abauladas medialmente, não deprimidas como nas demais espécies de Anthrenoides.

Holótipo macho. Comprimento aproximado 6,39; comprimento da asa anterior 5,30; largura da cabeça 2,04; altura da cabeça 1,44; comprimento do olho 1,08. Tegumento preto, exceto o clípeo e as máculas paroculares esbranquiçados, o clípeo com duas pequenas nódoas pretas nas proximidades das fóveas tentoriais e a margem castanha, as máculas paroculares muito pequenas, somente junto aos olhos e com o contorno irregular; antenas com o escapo, pedicelo e dois flagelômeros basais pretos, os demais flagelômeros castanhoenegrecidos dorsalmente e castanho-ocráceos na face ventral a partir da ponta do segundo flagelômero; tégulas castanhoenegrecidas, translúcidas; asas tingidas de castanho-pálido; pernas enegrecidas, sem mácula amarela na base das tíbias; esporões mesotibiais castanhos; tergos enegrecidos com faixa marginal um pouco translúcida mas também enegrecida, os esternos castanho-escuros, com faixa marginal translúcida castanho-pálida.

Placa labral quase retangular, sem carenas laterais; clípeo polido com carena baixa e pontos grandes separados por intervalos variáveis, os maiores com o tamanho do ocelo; supraclipeal elevada junto á carena frontal, micro-reticulada, com pontos esparsos no disco e densos em direção à área interalveolar; carena frontal fina até pouco acima dos alvéolos; fóveas faciais curtas e estreitas, um pouco arqueadas para o meio, medindo aproximadamente $1 / 4$ do comprimento dos olhos $(0,24: 1,08)$; genas fracamente angulosas; mesoscuto e escutelo polidos, no mesoscuto os pontos finos e separados por espaços de 3 a 4 diâmetros de ponto, e no escutelo um pouco maiores e mais afastados; mesepisternos micro-reticulados; depressão basal do propódeo mais longa que o metanoto, com rúgulas finas pouco evidentes e rebordo posterior somente no meio; tergo basal polido e com os pontos como no mesoscuto, segundo e terceiro tergos polidos com pontos mais densos, os demais tergos brilhantes, com microreticulação muito fraca, sexto esterno com carena basal em arco contínua com os bordos laterais.

Pilosidade branca, esparsa nos tergos, no sexto formando franja longa, rala e decumbente, tergo distal com pêlos castanho-pálidos.

Holótipo macho. BRASIL. Paraná: "Brasil, Paraná, Guarapuava, Pq. [Parque] das Araucárias, 23.X. / 2003, G. Melo" (DZUP). Parátipo de São Paulo: Sete Barras, 24.IX.2002, Aguiar, A. J. C. leg., 1 macho (DZUP).

Comentário. A área mediana das paroculares um pouco abauladas medialmente, só foi constatada nesta espécie, nos demais Anthrenoides a região mediana das paroculares é deprimida. A. faviziae sp. nov. difere de A. guarapuavae sp. nov. pelo aspecto micro-reticulado do clípeo e pelo lóbulo ventral carenado das genas; e $A$. pinhalensis sp. nov., difere pelo mesoscuto micro-reticulado, tubérculo ventral das genas e pelas paroculares, deprimidas na região mediana.

\section{Anthrenoides guttulatus sp. nov.}

Diagnose. Macho com as paroculares inteiramente pretas, o clípeo com nódoa subapical amarela obsoleta, fóvea 

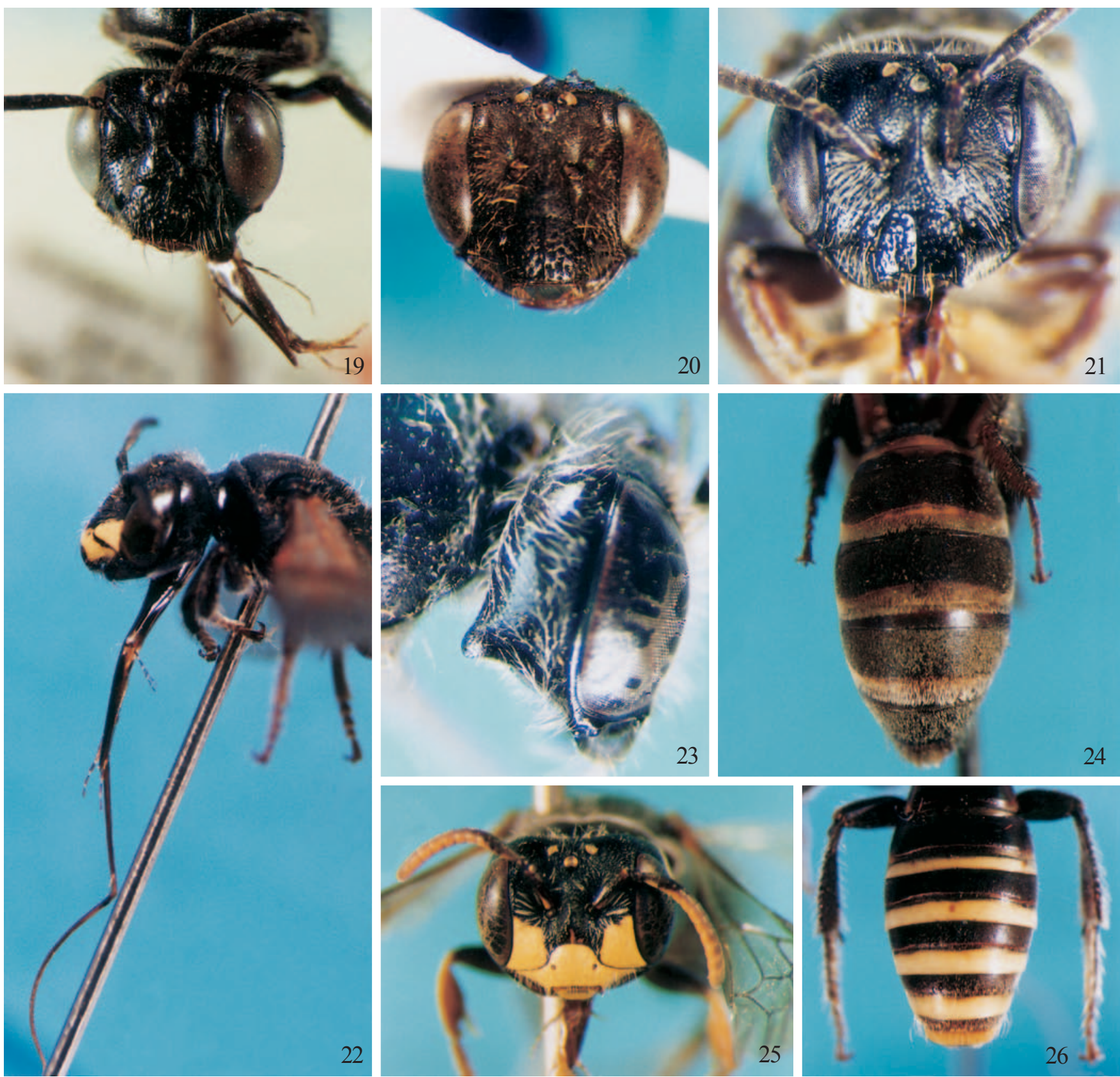

Figs. 19-26. Vista frontal da cabeça de (19) Anthrenoides corrugatus, fêmea; (20) A. densopunctatus, fêmea; (21) A. meloi, fêmea; (22) cabeça e mesossoma de A. admirabilis, macho; (23) perfil da cabeça de A. faviziae, macho; (24) tergos de A. langei, fêmea; (25) vista frontal da cabeça de A. micans, macho; (26) tergos de A. admirabilis, macho. Figs. 19-20, 22-26, holótipos; fig. 21, parátipo fêmea.

interalveolar alongada e em forma de gota, fóveas faciais rasas, mesoscuto micro-reticulado e o escutelo polido.

Holótipo macho. Comprimento aproximado 6,47; comprimento da asa 6,0 ; largura da cabeça 1,99 ; altura da cabeça 1,52; comprimento do olho 0,98 . Tegumento preto predominando, porém com uma tonalidade castanhoavermelhada em parte do clípeo, nas pernas e no metassoma; o clípeo com nódoa subapical amarela pouco conspícua. Antenas com escapo e pedicelo enegrecidos; tégulas castanho-amareladas; asas tingidas de castanho; tíbias sem nódoa amarela basal; esporões mesotibiais castanhos; tergos com larga faixa marginal castanho-pálida.

Placa labral curta e arredondada, com carenas laterais curtas junto ao ápice; clípeo com micro-reticulação rasa, sem carena e com pontos rasos, esparsos e micro-reticulados; área supraclipeal micro-reticulada como o clípeo, um pouco elevada em direção à fóvea interalveolar mediana, esta em forma de gota e orlada por carenas finas que se unem dorsalmente na carena frontal, tanto a fóvea como a carena frontal pouco mais 
longas que o ocelo mediano; fóveas faciais apenas marcadas, muito rasas, medindo aproximadamente $1 / 3$ do comprimento dos olhos $(0,34: 0,98)$; genas com angulosidade ventral; mesoscuto micro-reticulado com pontos rasos e esparsos, escutelo polido com pontos mais esparsos que no mesoscuto; mesepisternos micro-reticulados; depressão basal do propódeo pouco mais longa que a metade do metanoto, quase lisa, com rúgulas curtas e esparsas; primeiro tergo quase liso, com micro-reticulação fraca e pontos muito finos escassos; segundo e terceiro tergos brilhantes e com micro-reticulação superficial, os pontos finos e esparsos; nos demais tergos os pontos muito escassos, faixa marginal brilhante com microreticulação esparsa; sexto esterno com carena basal em arco, contínua com as margens laterais do mesmo.

Pilosidade branca menos na face ventral dos basitarsos, castanho-clara; quarto ao sexto tergo com franja esparsa longa e decumbente.

Holótipo macho. BRASIL. Paraná: “ Curitiba / 27.9.55”; [sem indicação do coletor] (DZUP).

Comentário. Como A. zanellai sp. nov., o macho tem o clípeo enegrecido com pequena área amarela subapical; difere pela fóvea interalveolar grande e pela depressão basal do propódeo curta, pouco maior que a metade do comprimento do metanoto. O holótipo está com a cabeça colada e, somente com a parte basal das antenas.

\section{Anthrenoides langei sp. nov.} (Fig. 24)

Diagnose. Fêmea com a placa labral quase quadrangular; supraclipeal micro-reticulada e denso-pontuada, tíbias posteriores com cerdas brancas, tergos com faixa marginal amarelo-âmbar e pilosidade curta e densa, amarelada.

Holótipo fêmea. Comprimento 8,33; comprimento da asa 6,77; largura da cabeça 2,44; altura da cabeça 1,92 ; comprimento do olho 1,36 . Tegumento preto na cabeça, com uma tonalidade avermelhada nas genas e mandíbulas; asas tingidas de amarelo-méleo, prestigma e pterostigma méleos; tíbias sem nódoa amarela basal; esporões mesotibiais castanho-alaranjados; mesossoma enegrecido com uma tonalidade um pouco avermelhada, tergos castanhoenegrecidos com a faixa marginal larga amarelo-âmbar, porém esbranquiçada e translúcida na ponta; esternos castanhos, quarto e quinto com faixa marginal amarelo-acastanhada e o sexto esterno em grande parte desta cor.

Placa labral quase quadrangular, arredondada nos cantos e com carenas nos lados dos $2 / 3$ distais, com rúgulas fraquíssimas divergentes do meio para os lados; clípeo microreticulado, com pontos grandes bem marcados e sem carena mediana; supraclipeal protuberante, micro-reticulada e com pontuação densa, os pontos menores que os clipeais; carena frontal longa e fina, até o ocelo mediano; fóveas faciais largas e marcadas por pontos pilígeros, tão longas como $1 / 3$ do comprimento dos olhos $(0,46: 1,36)$; mesoscuto e escutelo micro-reticulados, mesoscuto com pontuação densa e fina, os intervalos menores que os pontos, o escutelo com os pontos maiores que os do mesoscuto e muito esparsos; esporões mesotibiais quase tão longos como os basitarsos, sem espinhos; mesepisternos micro-reticulados; depressão basal do propódeo mais longa que o metanoto, com rúgulas esparsas, pouco divergentes nos lados; tergos com micro-reticulação densa, os pontos também densos.

Pilosidade branca na cabeça e mesossoma, amarelada nos tergos; tíbias e basitarsos anteriores e medianos com pêlos e cerdas castanhos, as cerdas brancas nas tíbias posteriores; face ventral dos mesepisternos com cerdas finas onduladas; nos tergos amarelada, muito curta, densa e decumbente.

Holótipo fêmea. BRASIL, Paraná: "Curitiba Pr [sic] / II-1955 / R. Lange leg" (DZUP). Parátipos de Curitiba, III.1956, R. Lange leg., 1 fêmea (LANGE); São Paulo: Campos do Jordão 1600 m, III.1945, Wygodzinsky leg., 12 fêmeas (DZUP).

Comentário. A fêmea com o mesocuto denso-pontuado, com os pontos maiores que os espaços entre os mesmos como em $A$. densopunctatus $\mathbf{s p . ~ n o v . , ~ q u e ~ t e m ~ o s ~ e s p o r o ̃ e s ~ m e s o t i b i a i s ~}$ armados com espinhos e a pilosidade do colar do pronoto com mescla de pêlos curtos e longos. Em A. langei os esporões mesotibiais não tem espinhos e o colar do pronoto é revestido com pêlos curtíssimos, grossos e densos.

Homenagem ao Prof. Rudolf Bruno Lange.

\section{Anthrenoides larocai sp. nov.} (Fig. 8)

Diagnose. Macho com clípeo e paroculares inferiores amarelos; fóveas faciais claviformes, tão largas dorsalmente como o dobro da largura na parte ventral; placa labral amarela com margem castanho-clara ou inteiramente castanha, mesoscuto polido com micropontos esparsos, escutelo polido, quinto esterno com carena fina subapical. Fêmea com a face alongada, placa labral com rúgulas divergentes e área basal com rúgulas anastomosadas; fóveas faciais maiores do que nos machos e com alargamento dorsal medindo cerca de uma vez e meia a largura da área ventral.

Holótipo macho. Comprimento aproximado 8,42; comprimento da asa 5,79; largura da cabeça 2,18; altura da cabeça 1,89; comprimento do olho 1,28. Tegumento preto na cabeça e dorso do mesossoma, as genas com leve tonalidade avermelhada; placa labral amarela com área basal acastanhada; clípeo e paroculares inferiores amarelos, o clípeo com duas nódoas enegrecidas próximas às fóveas tentoriais e castanho na ponta, as máculas paroculares até a metade da sutura subantenal externa e alongadas junto às órbitas terminando pouco abaixo da tangente alveolar inferior; antenas com a face ventral castanho-ocrácea. Asas tingidas de amarelo-méleo, o pterostigma também desta cor; tégulas amareloacastanhadas; pernas castanho-escuras, um pouco avermelhadas; tíbias sem nódoa amarela basal; os tarsômeros, exceto os basitarsos, amarelo-pálidos nas pernas anteriores e 

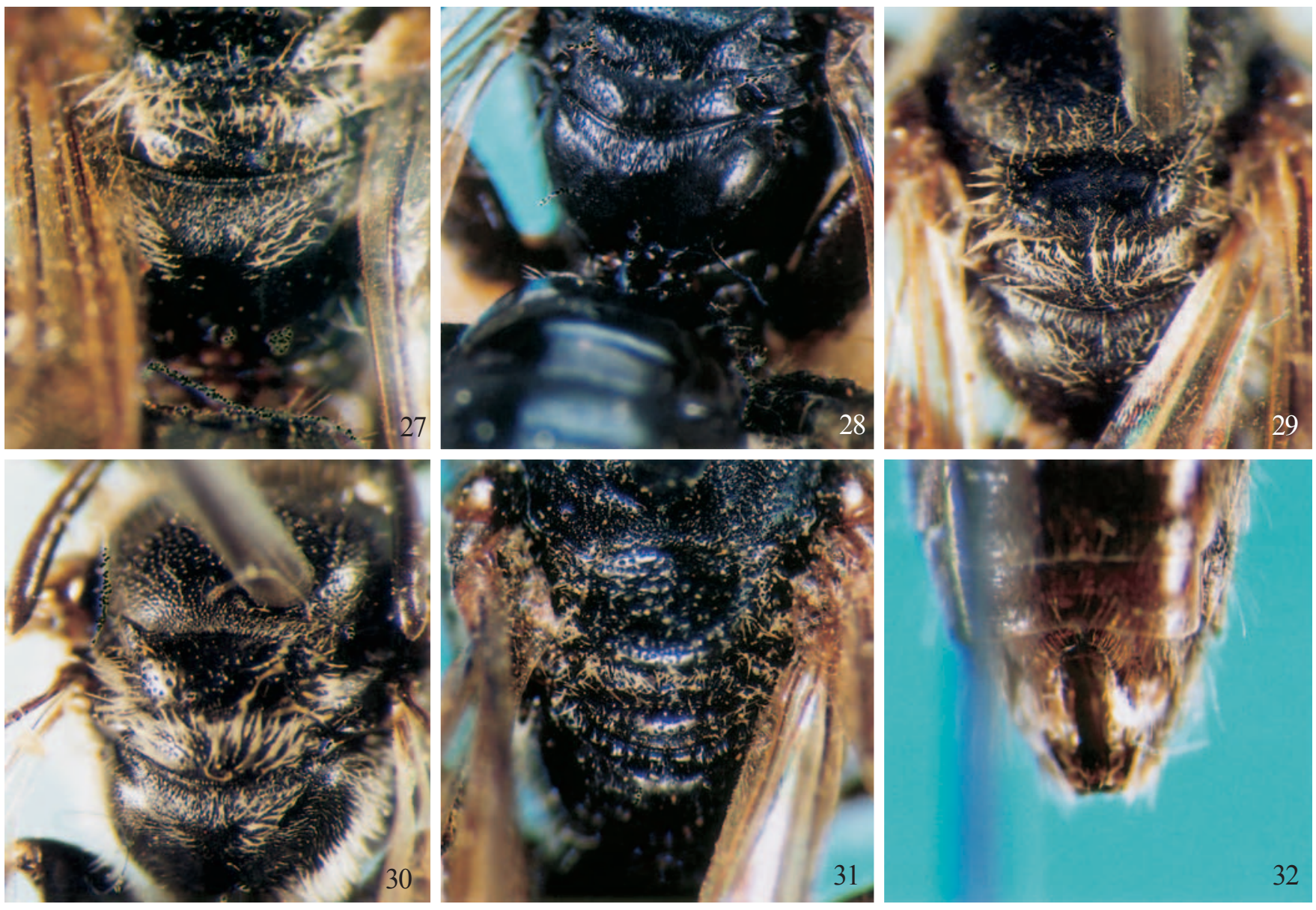

Figs. 27-32. Escutelo e propódeo (27-31); (27) Anthrenoides corrugatus, fêmea; (28) A. cyphomandrae, fêmea; (29) A. ornatus, fêmea; (30) A. politus, fêmea; (31) A. serranicola, macho. (32) Esternos distais de A. zanellai, macho. Figs. 27-28, 30-31, holótipos; figs. 29 e 32, parátipos.

medianas e com uma tonalidade acastanhada nos posteriores; esporões mesotibiais castanhos; os três tergos basais castanho-avermelhados e os seguintes mais enegrecidos, com faixa marginal larga castanha, o basal e o apical mais amarelados; esternos castanho-amarelados com áreas enegrecidas.

Placa labral retangular, com carenas laterais curtíssimas junto ao ápice; clípeo polido com pontos grandes distribuídos irregularmente, sem carena mediana; supraclipeal brilhante, inflada e com micro-reticulação fraca, os pontos separados por espaços irregulares; fronte um pouco elevada e com carena baixa curtíssima; fóveas faciais claviformes, estreitadas ventralmente, pouco maiores que $1 / 4$ do comprimento dos olhos $(0,36: 1,28)$; genas com angulosidade ventral obtusa; mesoscuto polido, com micropontos esparsos e pontos pequenos também esparsos, mais densos em volta; escutelo polido com os pontos maiores e mais esparsos que os do mesoscuto; mesepisternos micro-reticulados; depressão basal do propódeo mais longa que o metanoto e com rúgulas até o rebordo e áreas com micro-esculturação irregular, rebordo posterior fracamente delimitado; tergos com pontuação densa e faixa marginal lineolada larga, brilhante; quinto esterno com uma carena subapical angulosa e fina na área mediana; sexto esterno com carenas basais convergentes separadas por distância igual ao diâmetro do flagelo.

Pilosidade branca predominando, amarelo-creme na face ventral dos basitarsos; primeiro ao quarto tergo com franjas laterais, quinto e sexto com franja rala decumbente na faixa marginal.

Fêmea. Comprimento aproximado 8,44; comprimento da asa 5,92; largura da cabeça 2,32; altura da cabeça 2,10 ; comprimento do olho 1,51. Cabeça de um castanhoavermelhado escuro; paroculares inferiores com mácula um pouco avermelhada, muito estreita junto às suturas subantenais externas e não chegando às órbitas; mandíbulas e genas castanho-avermelhadas; antenas castanho-escuras dorsalmente e de um amarelo-palha na face ventral, a partir do terceiro flagelômero; asas tingidas de amarelo-acastanhado; pernas castanhas sem nódoa amarela na base das tíbias; esporões mesotibiais castanhos; tergos enegrecidos com áreas castanho-avermelhadas e larga margem castanha mais clara; esternos em parte enegrecidos e em parte castanhoamarelados. 
Placa labral quadrangular, ladeada com carenas finas nos 2/3 distais, com uma área basal semi-circular irregularmente esculturada e com numerosas rúgulas divergentes; clípeo e supraclipeal polidos com pontos separados por espaços irregulares e micropontos distribuídos irregularmente; clípeo sem carena mediana; área supraclipeal protuberante; carena frontal baixa com sulco muito fino, até pouco acima da tangente alveolar; fóveas faciais maiores que as do macho, estreitas ventralmente e quase duplicando a largura na parte superior, tão longas como $1 / 3$ do comprimento dos olhos $(0,51: 1,51)$; mesoscuto micro-reticulado com pontuação densa e algumas áreas sem pontos no disco; escutelo polido com pontos muito esparsos; esporões mesotibiais pouco menores que o respectivo basitarso e com 5 espinhos; mesepisternos microreticulados; depressão basal do propódeo como no macho; tergos micro-reticulados com pontos finos e larga faixa marginal micro-reticulada um pouco brilhante.

Pilosidade branca, porém na face ventral dos basitarsos anteriores amarelo-acastanhada, e na dos demais basitarsos, castanha; face dorsal das tíbias posteriores com cerdas enegrecidas e cerdas castanhas com a ponta esbranquiçada; mesepisternos com cerdas semi-decumbentes arqueadas; no quinto tergo castanha e no sexto castanho-amarelada; segundo ao quarto tergo com franjas só nos lados.

Holótipo macho. BRASIL. Paraná: "Colombo, PR / Brasil XI-63 / S. Laroca leg." (DZUP). Parátipos com os mesmos dados do holótipo, 1 macho e 1 fêmea; Paraná: [Ponta Grossa] Vila Velha, 28.X.1969, Pe. J. S. Moure leg., um macho; São José dos Pinhais, 18.XI.1966, S. Laroca - Antoni leg., uma fêmea (DZUP).

Comentário. O macho, como A. serranicola sp. nov. e $A$. faviziae sp. nov., tem carenas laterais convergentes junto à base do recorte em "U", no sexto esterno; porém A. serranicola tem o clípeo preto e $A$. faviziae tem as máculas cefálicas esbranquiçadas. O parátipo macho de Vila Velha, tem uma anomalia na base do sexto esterno, uma concavidade profunda e brilhante junto às carenas basais, em vez da superfície plana. Os dois parátipos machos têm a placa labral castanhoenegrecida.

Em homenagem ao Prof. Dr. Sebastião Laroca, Departamento de Zoologia, UFPR.

\section{Anthrenoides magaliae sp. nov.}

(Fig. 9)

Diagnose. Macho com o clípeo castanho, contornado irregularmente com amarelo, com uma estria mediana também amarela; paroculares inferiores com máculas amarelas curtas e largas lembrando um ângulo reto, mais longas junto às suturas subantenais externas.

Holótipo macho. Comprimento aproximado 5,73; comprimento da asa 4,51; largura da cabeça 1,78; altura da cabeça 1,35; comprimento do olho 1,04 . Tegumento preto predominando na cabeça, com uma tonalidade castanha na supraclipeal e na parte posterior do vértice; nas genas castanho-avermelhado; labro e quase todo o clípeo castanhos, o clípeo com orla amarela irregular junto à sutura epistomal e uma estria mediana, também amarela; máculas amarelas das paroculares inferiores com a forma de um " $\mathrm{L}$ " curto e largo, mais curtas junto às órbitas, aí quase igualando o diâmetro dos ocelos e mais longas perto das áreas subantenais, chegando até a metade das suturas subantenais externas; antenas castanho-avermelhadas dorsalmente e, na face ventral de um castanho-claro a partir do terceiro flagelômero. Mesoscuto e escutelo pretos, demais áreas do mesossoma castanho-enegrecidas; pernas castanho-pálidas, as tíbias anteriores e medianas com pequena mancha amarela basal, a placa basitibial castanho-pálida com orla preta; esporões mesotibiais esbranquiçados; tergos castanho-enegrecidos, um pouco avermelhados, com a faixa marginal amareloacastanhada larga e translúcida; esternos castanhos com margem larga amarelo-acastanhada.

Placa labral curta e arredondada, com carenas laterais curtas junto ao ápice; clípeo polido e sem carena, com pontos grandes muito esparsos; supraclipeal elevada e polida com pontos só nos lados; fronte com elevação em carena baixa e sulco fino mediano, a elevação um pouco protuberante dorsalmente e sobrepassando a área interalveolar; fóveas faciais brilhantes e estreitas, medindo aproximadamente um $1 / 4$ do comprimento dos olhos $(0,24: 1,04)$; genas estreitas ventralmente; mesoscuto micro-reticulado com pontuação densa na base, os intervalos maiores no disco; escutelo polido, com pontos maiores que os do mesoscuto; mesepisternos microreticulados; depressão basal do propódeo mais longa que o metanoto, micro-esculturada e com rúgulas irregulares um pouco anastomosadas, o rebordo posterior um pouco elevado; tergos com micro-reticulação densa e faixa marginal lineolada; sexto esterno com carena basal em arco.

Pilosidade branca, porém na face ventral dos basitarsos com cerdas de cor creme; tíbias posteriores com cerdas brancas; nos tergos curta e esparsa, o quinto e o sexto com franja rala de cerdas finas decumbentes.

Holótipo macho. BRASIL. Rio Grande do Sul: "Viamão RS / Brasil 7-V-1986 / M. Hoffmann col.” (DZUP).

Comentário. O colorido do clípeo e o formato das máculas paroculares distinguem esta espécie das demais. O metassoma do holótipo está colado em um cartão.

Dedicada à Dra. Magali Hoffmann, Laboratório de Proteção de Plantas, Universidade Estadual do Norte Fluminense.

\section{Anthrenoides meloi sp. nov.}

(Figs. 10, 21)

Diagnose. Macho com placa labral preta, clípeo amarelo, paroculares inferiores com máculas amarelas quadrangulares, fóveas faciais estreitas ventralmente e largas na parte dorsal, mesoscuto e escutelo polidos. Fêmeas com carena mediana ao longo do clípeo e as fóveas faciais com a metade dorsal tão larga como o dobro da ventral. 
Holótipo macho. Comprimento aproximado 6,40; comprimento da asa 5,18; largura da cabeça 2,34; altura da cabeça 1,58; comprimento do olho 1,28 . Tegumento preto na cabeça menos as genas castanho-avermelhadas, o clípeo amarelo margeado distalmente com castanho e com duas manchinhas pretas próximas das fóveas tentoriais; nódoas amarelas quadrangulares nas paroculares inferiores; antenas amarelo-palha ventralmente a partir do segundo flagelômero; mesossoma preto dorsalmente e castanho no lado ventral; pernas castanhas com pequena nódoa amarela na base da face externa das tíbias anteriores e medianas, tíbias anteriores com a face anterior amarelo-escura; esporões mesotibiais esbranquiçados; asas ferrugíneas; tergos castanhos com larga faixa marginal amarelo-âmbar.

Placa labral trapezoidal curta e larga, com carenas laterais quase até a base; clípeo polido, com pontos rasos e carena mediana desprovida de pontos; supraclipeal pouco elevada, brilhante e micro-reticulada, com pontos distribuídos irregularmente; fronte com sulco orlado por carenas finas, quase até o ocelo mediano, o sulco com pontos; fóveas faciais quase foscas, muito estreitas ventralmente e com o dobro da largura na parte dorsal, quase tão longas como $1 / 4$ do comprimento dos olhos $(0,34: 1,28)$; genas um pouco mais largas embaixo, sem angulosidade obtusa; mesoscuto e escutelo polidos, o mesoscuto com micro-reticulação muito fraca e pontos grandes mais densos em volta, os espaços maiores entre os pontos no disco, chegando a 5 diâmetros de ponto; escutelo com os pontos mais esparsos que os do mesoscuto; mesepisternos micro-reticulados; depressão basal do propódeo mais curta que o metanoto e com rúgulas; tergos densamente marcados por pontuação fina e rasa, com microreticulação irregular e faixa marginal brilhante, larga e microreticulada; sexto esterno com carena basal arredondada, contínua com os bordos laterais do mesmo.

Pilosidade branca, curta e densa no metanoto; de um amarelo-âmbar na face ventral dos basitarsos; segundo ao quarto tergo com franjas esparsas aos lados, no quinto e sexto tergos com franja de pêlos longos, esparsos e decumbentes, nos tergos distais esbranquiçada.

Fêmea. Comprimento aproximado 9,03; comprimento da asa 5,14; largura da cabeça 2,53; altura da cabeça 2,25; comprimento do olho 1,36 . Tegumento preto na face, porém castanhoavermelhado nas genas e parte do vértice; antenas, castanhoamareladas ventralmente do ápice do terceiro flagelômero ao distal; dorso do mesossoma preto menos as partes laterais do propódeo, face ventral do mesossoma e os artículos basais das pernas, castanho-avermelhados; nódoa amarela basal na face externa das tíbias anteriores e medianas; esporões mesotibiais castanhos; tégulas enegrecidas na base e castanho-amareladas na metade apical; asas ferrugíneas; tergos castanho-enegrecidos com faixa marginal larga e translúcida, de um amarelo levemente acastanhado, os tergos basais com uma tonalidade avermelhada.

Placa labral fracamente trapezoidal, um pouco mais estreita na ponta, com carenas laterais quase até a base, ornada com algumas rúgulas basais irregulares; clípeo polido com a carena mediana mais evidente do que no macho, larga e com os lados divergentes junto à sutura epistomal; supraclipeal e fronte como no macho; fóveas faciais muito largas e quase quadradas na metade dorsal, medindo mais de $1 / 3$ do comprimento dos olhos $(0,51: 1,36)$; esporões mesotibiais com 7 espinhos pequenos. Mesoscuto, escutelo, mesepisternos, depressão basal do propódeo e tergos como no macho.

Pilosidade branca predominando, passando a castanha e densa no quinto e sexto tergos; face ventral dos mesepisternos com cerdas finas eretas e com as pontas dobradas em gancho; nos basitarsos anteriores e na face ventral dos demais basitarsos amarelo-âmbar; tíbias posteriores com cerdas brancas na face dorsal; faixa marginal dos tergos com pêlos muito curtos decumbentes.

Holótipo macho. BRASIL. Paraná: "Vila Velha [Ponta Grossa] PR / Brasil 15-XI-65 / Moure e Marinoni” (DZUP). Parátipos. Com os mesmos dados de etiqueta do holótipo, 3 machos e 18 fêmeas; Parque Estadual de Vila Velha [Ponta Grossa], 09.XI.2002, G. A. R. Melo \& R. B. Gonçalves leg., 1 macho (DZUP).

Comentário. Fóveas faciais com a metade ventral estreita $\mathrm{e}$ a dorsal larga como em $A$. larocai sp. nov. O macho de $A$. larocai difere por ter carena subapical curta no quinto esterno e carenas basais convergentes no sexto esterno, A meloi tem o quinto esterno liso e o sexto com carena basal reta. As fêmeas de $A$. larocai não têm carena mediana no clípeo.

Em homenagem ao Prof. Dr. Gabriel Augusto Rodrigues de Melo, Departamento de Zoologia, UFPR.

\section{Anthrenoides ornatus sp. nov.}

$$
\text { (Figs. 11, 29) }
$$

Diagnose. Macho com as paroculares e o clípeo castanhoenegrecidos, sem máculas amarelas; genas com tubérculo ventral alargado, piramidal; fóveas faciais muito rasas, fronte com carena fina e longa. Fêmea com fóveas faciais mais longas que $1 / 3$ do comprimento do olho, clípeo, mesoscuto e escutelo micro-reticulados.

Holótipo macho. Comprimento aproximado 7,88; comprimento da asa 6,47; largura da cabeça 2,69; altura da cabeça 1,73; comprimento do olho 1,22. Tegumento castanhoenegrecido levemente avermelhado; pernas e propódeo castanho-avermelhados; tergos e esternos amareloacastanhados com um toque de ferrugíneo e a faixa marginal castanha; antenas castanho-enegrecidas na face dorsal e, na ventral com os flagelômeros castanho-ocráceos a partir da ponta do terceiro; tégulas castanhas translúcidas; asas tingidas de amarelo-acastanhado; tíbias sem nódoa amarela na base; esporões mesotibiais castanho-escuros.

Placa labral semi-circular; clípeo polido porém com áreas fracamente micro-reticuladas e pontos pequenos esparsos, levemente deprimido ao longo do meio e com as projeções látero-apicais digitiformes; supraclipeal um pouco elevada em direção à fronte, micro-reticulada e com pontos rasos esparsos; 
fronte com carena interalveolar; fóveas faciais rasíssimas, pouco maiores que $1 / 3$ do comprimento dos olhos $(0,43: 1,22)$; genas com projeção ventral maior que o ocelo, de forma piramidal; mesoscuto e escutelo brilhantes, com microreticulação pouco marcada, os pontos não densos, separados por espaços de 2 a 4 diâmetros de ponto, mais esparsos e maiores no escutelo; depressão basal do propódeo tão longa como o metanoto, um pouco elevada posteriormente, sem rúgulas e micro-reticulada; tergos polidos com pontos finos um pouco densos, a faixa marginal larga e brilhante um pouco marcada por micro-reticulação; sexto esterno com carena basal em arco.

Pilosidade branca, porém amarelo-âmbar na face ventral dos basitarsos; lados do segundo ao quarto tergo com pêlos longos, decumbentes e esparsos, quinto e sexto tergos com faixa marginal decumbente e esparsa.

Fêmea. Comprimento aproximado 6,78; comprimento da asa 5,85; largura da cabeça 2,11; altura da cabeça 1,68; comprimento do olho 1,20. Tegumento da cabeça e mesossoma como no macho. Tergos castanho-enegrecidos com áreas levemente avermelhadas.

Placa labral trapezóide com rúgulas basais divergentes e irregulares e uma rúgula longa mediana, carenas laterais quase até a base; clípeo brilhante com micro-reticulação fraca e pontos rasos esparsos; supraclipeal e carena frontal como no macho; fóveas faciais brilhantes e rasas, um pouco mais largas na altura dos $2 / 3$ dorsais e estreitando a seguir, nitidamente mais longas que 1/3 dos olhos $(0,48: 1,20)$; mesoscuto e escutelo com micro-reticulação densa, quase foscos, no mesoscuto os pontos pouco maiores que os retículos, separados por distância variando de 2 a 4 diâmetros de ponto; escutelo com pontos pouco maiores e mais esparsos; esporões mesotibiais com 6 espinhos subapicais e alguns menores na base; depressão basal do propódeo tão longa como o metanoto, um pouco elevada posteriormente, sem rúgulas ou com rúgulas esparsas, micro-reticulada; tergos polidos com áreas microreticuladas e pontos pequenos, os pontos mais esparsos no basal, faixa marginal como no macho.

Pilosidade predominante branca, basitarsos com cerdas castanhas, mais escuras nos anteriores e medianos; face dorsal das tíbias posteriores com cerdas castanhas com a metade distal branca; esporões mesotibiais castanho-enegrecidos.

Holótipo macho. BRASIL. Rio Grande do Sul: "Pto. [Porto] Alegre / RS XI.1978 / A. D. leg.” (DZUP). Parátipos. Com os mesmos dados do holótipo, 17.XI.1978, 1 fêmea; Esteio, X.1942, sem indicação de coletor, 1 fêmea; Cruz Alta, XII.1953, sem indicação do coletor, 1 fêmea. Paraná: Curitiba, 1.XI.1955 e 27.XI.1955, Michener \& Lange leg., 2 fêmeas; 27.IX.1955, Moure, Michener \& Lange leg., 1 fêmea; Araucária, 14.X.1955, Mitchell \& Laroca leg., 1 fêmea; Colombo, 12.IX.1964, Moure \& Laroca leg., 1 fêmea (DZUP).

Comentário. O macho como o de A. zanellai sp. nov., com o tegumento da cabeça enegrecido e micro-reticulado, sem máculas amarelas, porém $A$. zanellai difere por não ter tubérculo piramidal nas genas. A fêmea difere de $A$. paolae $\mathbf{s p}$. nov., no colorido das cerdas das tíbias posteriores e depressão basal do propódeo.

\section{Anthrenoides palmeirae sp. nov.}

(Fig. 12)

Diagnose. Mesoscuto e escutelo micro-reticulados; macho com placa labral, clípeo e paroculares inferiores amarelos, supraclipeal brilhante no disco; fêmea com clípeo microreticulado brilhante, sem carena frontal, fóveas faciais curtas; tergos com pontuação densa e faixa marginal larga fosca, micro-reticulada.

Holótipo macho. Comprimento aproximado 6,70; comprimento da asa 4,75; largura da cabeça 2,16 ; altura da cabeça 1,65 ; comprimento do olho 1,27 . Tegumento preto na cabeça exceto: placa labral, clípeo e paroculares inferiores amarelos, o clípeo castanho-claro na margem e com duas nódoas castanhas próximas das fóveas tentoriais; máculas paroculares até a metade ventral da sutura subantenal externa, aumentando em comprimento em direção às órbitas; as genas castanhas e a supraclipeal um pouco avermelhada. Antenas castanho-escuras na face dorsal, com uma tonalidade mais clara para o ápice e, na face ventral, amarelo-ocráceas do ápice do flagelômero basal até o distal. Lado ventral do mesossoma, pernas e propódeo castanho-enegrecidos com uma tonalidade fracamente avermelhada; asas tingidas de castanho; tégulas amarelo-acastanhadas; tíbias com nódoa amarela na base, nas anteriores a nódoa prolongada até o meio da face ventral, nas posteriores a placa basitibial amarela; esporões mesotibiais esbranquiçados; tergos e esternos enegrecidos com faixa marginal castanha, mais pálida nos esternos.

Placa labral retangular, carenas laterais quase até a base do labro; clípeo com micro-reticulação fraca, pontos rasos separados por espaços de 1 a 2 diâmetros de ponto, sem carena mediana, com área desprovida de pontos junto ao ramo transversal da sutura epistomal; supraclipeal micro-reticulada, pouco elevada, com área discal sem pontos e pontuação densa nos lados; carena frontal finíssima com pequeno alvéolo inferior, ultrapassando um pouco a área interalveolar; fóveas faciais curtíssimas e muito estreitas, brilhantes, medindo cerca de 1/7 do comprimento dos olhos $(0,16: 1,27)$; genas com angulosidade ventral pouco marcada; mesoscuto, escutelo e mesepisternos micro-reticulados, o mesoscuto com pontos pequenos separados por espaços irregulares; escutelo com os pontos e os espaços entre os mesmos pouco maiores que os do mesoscuto; depressão basal do propódeo igualando a metade do comprimento do metanoto, com rebordo posterior e rúgulas entre espaços irregulares; primeiro ao terceiro tergo com pontuação densa e os espaços do tamanho dos pontos, a faixa marginal micro-reticulada; sexto esterno com carena basal em arco.

Pilosidade branca predominando; creme-amarelada na face ventral dos basitarsos; esparsa nos tergos, lados do terceiro e quarto com franjas ralas, quinto tergo com pilosidade esparsa e decumbente na faixa marginal e o sexto com franja longa e decumbente subapical.

Fêmea. Comprimento aproximado 7,41; comprimento da asa 
5,30; largura da cabeça 2,26; altura da cabeça 1,87 ; comprimento do olho 1,39. Tegumento preto na cabeça e dorso do mesossoma menos as genas, face ventral do mesossoma, pernas e propódeo de um castanho-escuro um pouco avermelhado; antenas castanhas dorsalmente, na face ventral amarelo-ocráceas a partir do terceiro flagelômero; asas tingidas de castanho-amarelado; tíbias anteriores e medianas com nódoa amarela basal, placa basitibial castanha; esporões mesotibiais esbranquiçados; tergos pretos com faixa marginal castanha larga e o bordo amarelo-creme.

Placa labral quadrangular com as carenas laterais ultrapassando os $2 / 3$ distais, com rúgulas divergentes junto à articulação labro-clipeal; clípeo brilhante e com pontos grandes, com micro-reticulação irregular na metade dorsal e no restante quase polido; supraclipeal protuberante com microretículo fino esparso e pontos irregulares; fronte elevada no meio, sem carena; fóveas faciais quase foscas, alargando um pouco dorsalmente, medindo aproximadamente $1 / 4$ do comprimento dos olhos $(0,36: 1,39)$; mesoscuto e escutelo micro-reticulados porém brilhantes, com pontuação mais densa no mesoscuto; depressão basal do propódeo igualando a metade do comprimento do metanoto, com rebordo posterior marcado e rúgulas entre espaços irregulares; do primeiro ao terceiro tergo com pontuação densa e os espaços igualando os pontos ou pouco maiores, faixa marginal com microreticulação densa e bem marcada.

Pilosidade branca e creme; na face ventral dos basitarsos creme-amarelada, tíbias posteriores com cerdas longas brancas, no quinto e sexto tergos castanho-pálida; área ventral dos mesepisternos com cerdas onduladas, tergos com pelinhos curtos formando faixa rala no terceiro e quarto.

Holótipo macho. BRASIL. Paraná: "R[io dos]. Papagaio[s] [Palmeira] PR / Brasil X-59 / P. D. Hurd leg" (DZUP). Parátipo com os mesmos dados do holótipo, 1 fêmea; [Ponta Grossa] Vila Velha, 15.X.1966, Moure \& Marinoni leg., 1 fêmea (DZUP).

Comentário. O macho com a placa labral amarela e o mesoscuto micro-reticulado como em $A$. reticulatus sp. nov., que difere pela mácula amarela do ápice do escapo e pela microreticulação densa da cabeça. As pernas estão danificadas nos parátipos fêmeas.

\section{Anthrenoides paolae sp. nov.}

Diagnose. Clípeo e supraclipeal micro-reticulados; mesoscuto e escutelo também com micro-reticulação densa. Fêmea com a placa labral ornada com rúgulas basais muito fracas, um pouco arqueadas; sem nódoa amarela na base das tíbias; macho com a placa labral preta, máculas cefálicas amarelas; depressão basal do propódeo com rúgulas divergentes e contorno posterior elevado.

Holótipo fêmea. Comprimento aproximado 7,17; asa danificada; largura da cabeça 2,37; altura da cabeça 1,75 ; comprimento do olho 1,52. Tegumento preto na cabeça e mesossoma; as antenas castanhas dorsalmente e de um amarelo-palha ventralmente a partir do terceiro flagelômero; asas tingidas de castanho, pterostigma castanho-escuro; tégulas translúcidas amarelo-acastanhadas na metade distal e enegrecidas na basal; pernas enegrecidas com um pouco de avermelhado, sem nódoa amarela na base das tíbias; esporões mesotibiais castanhos; tergos e esternos pretos, os tergos com margem castanha e os esternos com faixa marginal translúcida amarelada.

Placa labral quase quadrangular com rúgulas basais muito fracas, as carenas laterais ultrapassando os 2/3 distais; clípeo micro-reticulado com pontos também micro-reticulados; supraclipeal protuberante e micro-reticulada, com pontos menores que os do clípeo; carena frontal fina e longa até o ocelo; fóveas faciais grandes e muito rasas, quase imperceptíveis, micro-pontuadas, um pouco mais largas dorsalmente e quase tão longas como $1 / 3$ do comprimento dos olhos $(0,49$ : 1,52); mesoscuto e escutelo foscos, com micro-reticulação densa e pontos esparsos do tamanho dos micro-retículos; mesepisternos foscos, com micro-reticulação densa; esporões mesotibiais quase tão longos como os respectivos basitarsos, com 5 espinhos; depressão basal do propódeo um pouco mais curta que o metanoto, com rúgulas distribuídas irregularmente; tergos com micro-reticulação densa, foscos e quase sem pontos, com a faixa marginal pouco distinta da área discal.

Pilosidade predominante branca, porém castanhoamarelada na face ventral dos basitarsos, com uma tonalidade mais pálida nos posteriores; tíbias posteriores com cerdas longas brancas; mesepisternos com cerdas finas eretas com as pontas dobradas em gancho; franja densa castanho-pálida no quinto tergo.

Macho. Comprimento aproximado 7,5; asa anterior 6,08; largura da cabeça 2,36; altura da cabeça 1,72; comprimento do olho 1,30 . Tegumento preto, clípeo e paroculares inferiores amarelos, o clípeo com duas nódoas pequenas aos lados e a margem enegrecidas; as máculas paroculares grandes, em forma de gota, com o contorno dorsal emarginado, da metade da sutura subantenal externa até o olho; antenas de um castanhoâmbar a partir da ponta do segundo flagelômero; tégulas castanhas translúcidas, asas tingidas de castanho e pernas pretas sem mácula amarela nas tíbias; tergos e esternos castanho-enegrecidos com faixa marginal castanha, translúcida só na ponta.

Placa labral retangular; clípeo micro-reticulado quase fosco com pontos pequenos e rasos; supraclipeal micro-reticulada com os pontos mais rasos que os do clípeo, elevada para o meio; carena frontal mais alta entre os alvéolos e fíníssima dorsalmente até o ocelo mediano; fóveas faciais um pouco alargadas dorsalmente, medindo cerca de $1 / 5$ do comprimento dos olhos $(0,24: 1,30)$; genas angulosas, sem tubérculo ventral; mesoscuto e escutelo micro-reticulados com pontos esparsos, no mesoscuto os pontos como os retículos e no escutelo um pouco maiores; depressão basal do propódeo tão longa como o metanoto com rúgulas divergentes e contorno posterior elevado no meio; tergos micro-reticulados com pontos finos, 
os pontos muito esparsos no primeiro e densos no segundo e terceiro tergos; faixa marginal dos tergos micro-reticulada e brilhante; sexto esterno com carena basal em arco, prolongada medianamente para a base do esterno em forma de carena um pouco mais larga.

Holótipo fêmea. BRASIL. Paraná: "Curitiba - Paraná / Brasil 23/ 9/1955 / Moure \& Michener” (DZUP). Parátipos. Paraná: Lapa, Fazenda Sta. Bernadete, 29.VIII.1959, R. B. Lange leg., 1 macho (DZUP); 29.VIII. 1959, 1 fêmea (DZUP); sem indicação de data, R. Braga leg., 1macho (DZUP); Curitiba, Barigui, 19.IX.1959, R. B. Lange leg., 1 macho (LANGE); 22.IX.1959, 1 macho (LANGE); [Ponta Grossa], Parque Estadual de Vila Velha, 6.IX.2003, G. A. R. Melo \& R. B. Gonçalves leg., 1 fêmea (DZUP).

Comentários. As fêmeas de $A$. ornatus sp. nov. e de $A$. densopunctatus sp. nov. também têm a cabeça e o mesossoma micro-reticulados e quase foscos, como também as fóveas faciais grandes e muito rasas; A. ornatus tem pontuação esparsa no escutelo, deixando grandes áreas desprovidas de pontos, e a placa labral lisa, ao passo que $A$. densopunctatus tem pontuação muito densa no mesoscuto e no escutelo. $\mathrm{O}$ macho de $A$. paolae, como o de $A$. reticulatus sp. nov., tem o clípeo, supraclipeal, mesoscuto e escutelo micro-reticulados; o mesoscuto com pontos rasos e igualando o tamanho dos retículos. Entretanto, o macho de $A$. reticulatus difere por ter nódoa amarela no escapo, labro amarelo e fóveas irregulares na depressão basal do propódeo. A pilosidade do holótipo de A. paolae está danificada no dorso do mesossoma, parte dorsal dos tergos e dos mesepisternos. No parátipo fêmea as rúgulas da placa labral são pouco perceptíveis e a carena frontal mais curta. R. B. Lange coletou exemplares em flores de Mimosa scabrella Bent. (Leguminosae) e Baccharis elaeagnoides Steud. (Asteraceae).

Em homenagem à Paola Marchi.

\section{Anthrenoides paranaensis sp. nov.}

Diagnose. Fêmea com a cabeça micro-reticulada, placa labral retangular e sem rúgulas, supraclipeal com pontos muito rasos, carena frontal curta e finíssima, fóveas faciais longas e com micro-esculturação irregular, escutelo micro-reticulado, mesepisternos com cerdas onduladas na face ventral.

Holótipo fêmea. Comprimento aproximado 6,24; comprimento da asa 4,76; largura da cabeça 1,96; altura da cabeça 1,48; comprimento do olho 1,20. Tegumento preto, antena amarelo-acastanhada a partir do ápice do terceiro flagelômero; asas tingidas de castanho, prestigma castanhoenegrecido, pterostigma castanho porém com uma tonalidade mais clara no centro; tíbias anteriores e medianas com nódoa basal amarelo-esbranquiçada; esporões mesotibiais castanhos; faixa marginal dos tergos levemente avermelhada, esternos com a margem translúcida esbranquiçada.

Placa labral retangular com as carenas laterais nos 2/3 distais e rúgulas irregulares subapicais; clípeo micro-reticulado com pontos grandes também micro-reticulados, porém polido e com pontos maiores nas proximidades do labro; supraclipeal micro-reticulada com pontos muito rasos e pouco visíveis; carena frontal pouco conspícua, finíssima, até a metade da fronte; paroculares, fronte e vértice com pontos muito rasos e micro-reticulados; fóveas faciais brilhantes, com microesculturação irregular, medindo menos de 1/4 do comprimento dos olhos $(0,28: 1,20)$; mesoscuto e escutelo micro-reticulados com pontos esparsos, pequenos e muito rasos, pouco maiores que os retículos, os pontos mais fundos no escutelo; mesepisternos micro-reticulados; esporões mesotibiais tão longos como $2 / 3$ do comprimento dos basitarsos e com 7 espinhos finos; depressão basal do propódeo tão longa como o metanoto, sem rebordo posterior, com micro-esculturação e rugosidades irregulares; nos três tergos basais com microreticulação irregular e pontos finos, rasos e esparsos, faixa marginal com micro-reticulação pouco evidente.

Pilosidade branca; face ventral dos basitarsos amarelomélea; tíbias posteriores com cerdas brancas na face externa; quinto e sexto tergos com pêlos castanhos; face ventral dos mesepisternos com cerdas onduladas; esparsa nos tergos, o terceiro e o quarto com franja decumbente subapical.

Holótipo fêmea. BRASIL. Paraná: "Brasil. Paraná. Parque

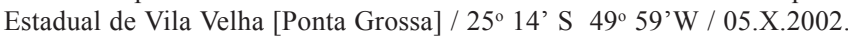
G. Melo / R. Gonçalves, A. Aguiar" (DZUP). Parátipo. Com a mesma procedência do holótipo, 6.IX.2003, G. A. R. Melo \& R. B. Gonçalves leg., 1 fêmea (DZUP).

Comentário. Clípeo micro-reticulado com pontos grandes como em $A$. densopunctatus sp. nov.; mesoscuto e escutelo também micro-reticulados porém com pontos pequenos, pouco maiores que os retículos, como em $A$. paolae sp. nov., que difere por ter as fóveas faciais rasíssimas e longas.

\section{Anthrenoides petuniae sp. nov.}

(Fig. 13)

Diagnose. Macho com a placa labral, clípeo e máculas paroculares amarelos; supraclipeal protuberante e sem microreticulação no disco, mesoscuto e escutelo polidos. Fêmea sem carena frontal, esporões mesotibiais com espinhos subapicais finos, tergos com pontuação densa e faixa marginal larga micro-reticulada.

Holótipo macho. Comprimento aproximado 6,70; comprimento da asa 4,57; largura da cabeça 1,98; altura da cabeça 1,48; comprimento do olho 1,12 . Tegumento preto na cabeça exceto as genas um pouco avermelhadas; placa labral, clípeo e paroculares inferiores amarelos, o clípeo com a margem e duas nódoas castanho-claras; as máculas paroculares quase até a metade ventral das suturas subantenais externas, aumentando irregularmente em direção aos olhos. Antenas castanhas na face dorsal, na ventral amarelo-ocráceas a partir do ápice do flagelômero basal; mesepisternos castanhoenegrecidos com uma tonalidade avermelhada. Asas tingidas de castanho; tégulas amarelo-acastanhadas; pernas castanhoavermelhadas, as tíbias anteriores com a face ventral amareloescura, nódoa amarela basal na face externa das tíbias 
anteriores e medianas; esporões mesotibiais esbranquiçados; propódeo e tergos castanho-amarelados, os tergos com a faixa marginal translúcida também castanho-amarelada; tergo distal e os esternos com uma tonalidade mais clara que a dos demais tergos.

Placa labral retangular com carenas laterais só junto ao ápice; clípeo polido com pontos esparsos muito rasos, sem carena mediana; supraclipeal inflada e polida no disco e com pontos distribuídos irregularmente nos lados; carena frontal curta, rasa e com sulco finíssimo no meio, prolongada dorsalmente em sulco fino pontilhado com orlas pouco elevadas também com pontos; fóveas faciais brilhantes, quase tão longas como $1 / 4$ do comprimento dos olhos $(0,27: 1,12)$; genas com angulosidade ventral obtusa; mesoscuto polido com pontos pequenos separados por espaços irregulares e áreas grandes sem pontos no disco; escutelo polido com pontos pouco maiores que os do mesoscuto; mesepisternos micro-reticulados; depressão basal do propódeo quase igual à metade do comprimento do metanoto, micro-esculturada $\mathrm{e}$ com rúgulas separando alvéolos curtos e irregulares, rebordo posterior um pouco elevado nos lados e bem evidente medialmente; primeiro ao terceiro tergos com pontuação densa e os espaços igualando os pontos ou pouco maiores, a faixa marginal micro-reticulada; sexto esterno com carena basal em arco, contínua com as margens laterais do mesmo.

Pilosidade branca, passando a creme-esbranquiçada na face ventral dos basitarsos; esparsa nos tergos, no quinto e sexto formando franja subapical longa, esparsa e decumbente.

Fêmea. Comprimento aproximado 7,84; comprimento da asa 5,68; largura da cabeça 2,48; altura da cabeça 1,86 ; comprimento do olho 1,38. Tegumento enegrecido, um pouco avermelhado; parte dorsal das antenas castanha e a ventral amarelo-âmbar a partir do ápice do primeiro flagelômero; asas castanho-amareladas; tíbias anteriores e medianas com nódoa amarela basal, placa basitibial preta; esporões mesotibiais amarelo-acastanhados; tergos com faixa marginal castanha.

Placa labral retangular alargada com as carenas laterais ultrapassando a metade do seu comprimento, sem rúgulas; clípeo polido com pontos rasos esparsos; supraclipeal brilhante, com micro-retículação esparsa e pontos irregulares, protuberante; fronte elevada no meio, com uma fóvea mediana pequena e alongada, sem carena; fóveas faciais largas, um pouco mais estreitas nas pontas e maiores que $1 / 3$ do comprimento dos olhos $(0,60: 1,38)$; mesoscuto em grande parte polido, com micro-reticulação somente nas proximidades do pronoto, pontuação irregular, os pontos pequenos; escutelo polido com pontos maiores que os do mesoscuto, densos, separados por espaços variáveis; esporões mesotibiais medindo aproximadamente dois terços dos basitarsos, com 2 a 4 espinhos subapicais finos; depressão basal do propódeo e tergos como no macho.

Pilosidade branca; nos basitarsos anteriores e na face ventral dos demais basitarsos amarelo-pálida; tíbias posteriores com cerdas brancas; área ventral dos mesepisternos com cerdas finas arqueadas nas pontas; tergos com pêlos curtos, no quinto e sexto castanhos muito pálidos.
Holótipo macho. BRASIL. Rio Grande do Sul: "Porto Alegre RS / Morro Santana / Brasil 04.11.1993 / O. Tschoepke leg." (DZUP). Parátipos. Com os mesmos dados do holótipo, 1 macho; da mesma localidade e coletor, 20.X.1993, 1 macho; 09.X.1991, 1 fêmea; 29.X.1993, 1 fêmea; 01.XI.1993, 2 fêmeas. Paraná: Campo Largo, 28.X.1965, S. Laroca leg., 1 macho; Curitiba, 1.XI.1955, Michener \& Lange leg., 3 machos; IX-X.1950, J. S. Moure leg., 1 macho; [Palmeira] R. Papagaio [Rio dos Papagaios], X.1959, P. D. Hurd leg., 2 machos; Araucária, 28.X.2000, G. Melo leg., 1 macho; Tibagi, 15 km SE, Faz. Sta. Lídia, $24^{\circ} 32^{\prime} \mathrm{S}, 50^{\circ} 16^{\prime} \mathrm{W}, 29 . X .2003$, G. A. R. Melo leg., 1 fêmea; Tibagi, 15 km SE, Iapó das Pedras 30.X.2003, 3 fêmeas e 1 macho; 31.X.2003, 1 macho (DZUP).

Comentário. Tanto G. A. R. Melo como O. Tschoepke coletaram espécimes em flores de Petunia Juss. [Solanaceae]. O macho, como o de $A$. palmeirae sp. nov., também tem a placa labral e o clípeo amarelos; porém A. palmeirae tem o mesoscuto e o escutelo micro-reticulados. Um dos parátipos machos de Morro de Santana tem a placa basitibial amarela.

\section{Anthrenoides pinhalensis sp. nov.}

(Fig. 14)

Diagnose. Tergos com tegumento em parte amarelo-âmbar ou arruivado. Macho com a placa labral preta, clípeo e máculas paroculares esbranquiçados, genas com tubérculo ventral, carena frontal longa e fina. Fêmea com o clípeo polido porém com micro-reticulação na metade dorsal, supraclipeal microreticulada; carena frontal finíssima, depressão basal do propódeo quase lisa; palpos labiais com os artículos distais pouco maiores que o diâmetro do ocelo médio.

Holótipo macho. Comprimento aproximado 8,58; comprimento da asa 6,27; largura da cabeça 2,57; altura da cabeça 1,63; comprimento do olho 1,39. Tegumento predominantemente preto, placa labral preta com mancha obscura subapical amarelo-acastanhada; clípeo e máculas paroculares esbranquiçados, o clípeo com a margem e duas nódoas pretas próximas às fóveas tentoriais, as máculas paroculares mais curtas que largas, chegando ao nível do ramo transversal da sutura epistomal. Asas tingidas de castanho; pernas e tergos castanho-avermelhados; tíbias sem nódoa amarela basal; esporões mesotibiais castanhos; os tergos com faixa marginal acastanhada, o basal amarelo-âmbar escuro na área vertical e no restante castanho-avermelhado, o segundo tergo com a faixa marginal amarelo-escura; esternos com uma tonalidade mais clara que a dos tergos, com áreas amareloâmbar e a margem esbranquiçada, o basal e o apical inteiramente amarelo-âmbar.

Placa labral quase retangular com carenas laterais junto ao ápice, um pouco inflada nos lados e levemente emarginada na ponta; clípeo polido com pontos rasos grandes e esparsos; supraclipeal micro-reticulada, pouco elevada, com pontos muito rasos, escassos e irregulares; fronte com carena fina da tangente alveolar inferior até o ocelo mediano; fóveas faciais brilhantes, medindo aproximadamente $1 / 4$ do comprimento dos olhos $(0,33: 1,40)$; genas com tubérculo ventral; mesoscuto micro-reticulado com pontuação rasa, fina e esparsa; escutelo 
polido com pontos esparsos no disco, maiores que os do mesoscuto; mesepisternos micro-reticulados; depressão basal do propódeo mais longa que o metanoto, com micro-reticulação fraca e rúgulas pouco marcadas nos cantos; tergos brilhantes com pontos finos e larga faixa marginal lisa fracamente lineolada, os pontos esparsos no tergo basal e densos nos demais; sexto esterno com a carena basal quase reta, contínua com os bordos laterais.

Pilosidade branca predominando, amarelada no vértice, mesoscuto e escutelo; cerdas de cor creme na face ventral dos basitarsos; amarelo-acastanhada no tergo distal; quarto ao sexto tergo com franja esparsa e decumbente.

Fêmea. Comprimento aproximado 9,41; comprimento da asa anterior 6,57; largura da cabeça 2,45; altura da cabeça 1,86; comprimento do olho 1,42. Tegumento preto na cabeça e dorso do mesossoma, pernas com áreas pretas, castanhas e amareloâmbar. Antenas ventralmente ocráceas do ápice do primeiro flagelômero ao distal e castanhas a partir do segundo, dorsalmente; tégulas castanho-enegrecidas, asas tingidas de castanho; esporão mesotibial castanho-claro; área amarelada no dorso dos metepisternos; primeiro ao quinto tergo amareloâmbar no disco com faixa marginal castanha e o bordo esbranquiçado translúcido, tergo distal enegrecido, esterno basal e o distal amarelo-âmbar, os tergos intermediários castanho-enegrecidos com máculas amarelo-âmbar e o bordo esbranquiçado, translúcido.

Placa labral com as carenas laterais nos $2 / 3$ distais, sem rúgulas, um pouco inflada dos lados, com a ponta arredondada e os lados retos junto ao clípeo; clípeo polido com área microreticulada basal, os pontos grandes, maiores que os espaços; supraclipeal micro-reticulada com os pontos tão grandes como os do clípeo na área discal; carena frontal finíssima, do meio da área interalveolar quase até o ocelo mediano; fóveas faciais elipsóides e largas, quase tão longas como $1 / 3$ do comprimento do olho $(0,49: 1,42)$; mesoscuto e escutelo micro-reticulados e brilhantes, com pontos separados por 1 a 2 diâmetros de ponto no mesoscuto, e um pouco mais dispersos no escutelo; esporão mesotibial com espinhos finos, os dois subapicais um pouco mais longos; depressão basal do propódeo longa como o metanoto, quase lisa, com 3 a 4 rúgulas longas e rebordo posterior marcado; mesepisternos micro-reticulados com pontos esparsos e finos; tergos inteiramente microreticulados com pontos muito pequenos pouco perceptíveis.

Pilosidade branca predominando, acastanhada no mesoscuto; castanha nas tíbias anteriores e com uma tonalidade mais enegrecida em todos os basitarsos, na face ventral dos basitarsos castanha; face dorsal das tíbias medianas com cerdas bicoloridas, castanhas na base e brancas no restante; levemente amarelada, curta e um pouco densa nos tergos; fina e ondulada na face ventral dos mesepisternos.

Holótipo macho. BRASIL. Paraná: "S. José Pinhais - PR / Brasil (Br 277 - km 54) / 08-16.VII.1984 / C. I. I. F. (Malaise)" (DZUP). Parátipos. Espírito Santo: Santa Tereza, 27.VIII.1967, C. T. \& C. Elias leg., 2 machos e 2 fêmeas; 22.IV.1967, C. T. \& C. Elias leg., 1 macho e 1 fêmea (DZUP).
Comentários. O holótipo foi coletado na mesma localidade que $A$. faviziae sp. nov., que é reconhecida pelo lóbulo ventral carenado das genas e pela micro-reticulação do clípeo e paroculares inferiores. Foi observada variação no colorido dos tergos, tanto nos machos como nas fêmeas, com o amareloâmbar predominando quase por inteiro ou castanho-escuros com áreas irregulares arruivadas.

\section{Anthrenoides politus sp. nov.}

(Fig. 30)

Diagnose. Fêmea com a placa labral quase quadrandular, clípeo polido e com pontos grandes, supraclipeal lisa e carena frontal fina e curta, fóveas faciais brilhantes e longas, mesoscuto micro-reticulado brilhante, escutelo polido.

Holótipo fêmea. Comprimento aproximado 9,03 [a cabeça encontra-se deslocada para a frente]; comprimento da asa 5,39; largura da cabeça 2,41; altura da cabeça 1,86; comprimento do olho 1,35 . Tegumento preto, menos as asas tingidas de um castanho fracamente amarelado, prestigma e pterostigma castanhos, a ponta do prestigma mais pálida; tíbias anteriores e medianas com nódoa amarelo-pálida; esporões mesotibiais castanhos; faixa marginal dos tergos castanha passando a amarelo-acastanhada em direção ao bordo.

Placa labral quase quadrangular, um pouco mais larga que longa e com a margem arredondada, com carenas laterais nos 2/3 apicais e poucas rúgulas basais esparsas, rasas; clípeo polido sem micro-reticulação e com pontos grandes e profundos, maiores que os espaços entre os mesmos; supraclipeal polida e protuberante, carena frontal fina e curta; fóveas faciais brilhantes, mais largas um pouco acima do meio e estreitando no terço dorsal, tão longas como $1 / 3$ do comprimento dos olhos $(0,45: 1,35)$; mesoscuto microreticulado e brilhante, com os pontos separados por espaços irregulares de 1 a 3 diâmetros de ponto, mais densa em volta; escutelo polido com pontos maiores que os do mesoscuto e mais separados; depressão basal do propódeo um pouco mais curta que o metanoto, com rúgulas paralelas densas no meio e mais irregulares e divergentes nos lados; esporões mesotibiais com 3 espinhos subapicais um pouco maiores e espinhos curtíssimos para a base; três tergos basais com microreticulação irregular e pontos finos densos no disco, faixa marginal larga e sem pontos.

Pilosidade branca, porém levemente amarelada nos basitarsos anteriores e de um amarelo-âmbar na face ventral dos basitarsos medianos e posteriores; tíbias posteriores com cerdas brancas na face dorsal; face ventral dos mesepisternos com cerdas finas com as pontas arqueadas em forma de gancho; nos tergos curta porém um pouco mais densa dos lados, no quinto e sexto castanha com mescla de pêlos brancos longos nos lados.

Holótipo fêmea. BRASIL. Paraná: "Brasil, Paraná, Parque / Estadual de Vila Velha [Ponta Grossa] 25 14' S 49 59' W / 09.XI.2002, G. A.R. Melo \& / R. B. Gonçalves" (DZUP). Parátipos. Com os mesmos dados do holótipo, 1 fêmea; da mesma procedência, 03.III.2001, G. A. 
R. Melo leg., 1 fêmea; Piraquara, Mananciais da Serra, $1.140 \mathrm{~m}$, 20.XI.2002, Melo, Aguiar \& Rozen leg., 1 fêmea; 3.XI.2002, A. J. C. Aguiar, G. Melo \& I. Alves dos Santos leg., 1 fêmea (DZUP).

Comentário. Como a fêmea de A. rodrigoi sp. nov., com o escutelo polido e com pontos esparsos e o clípeo também polido, porém o mesoscuto de A. politus é micro-reticulado e o de A. rodrigoi é polido.

Anthrenoides reticulatus sp. nov. (Fig. 15)

Diagnose. Macho com a cabeça, mesoscuto e escutelo com micro-reticulação densa, quase foscos; placa labral, clípeo e paroculares inferiores amarelos; fóveas faciais estreitas e brilhantes, escapo com mancha amarela apical e depressão basal do propódeo com alvéolos separados por trabéculas irregulares.

Holótipo macho. Comprimento aproximado 7,25; comprimento da asa 5,61; largura da cabeça 2,06; altura da cabeça 1,71; comprimento do olho 1,20 . Tegumento preto com exceção das seguintes áreas amarelas: placa labral, clípeo e paroculares inferiores, a placa labral castanha na base, o clípeo com fina orla e duas nódoas laterais pretas, as máculas paroculares até o terço inferior da sutura subantenal externa e mais longas junto às órbitas; antenas castanho-escuras com nódoa amarela apical na face ventral do escapo, amareloocráceas no lado ventral, a partir do segundo flagelômero. Tégulas castanhas; asas tingidas de amarelo-acastanhado na base, pterostigma castanho-escuro; pernas e esternos enegrecidos porém um pouco avermelhados; tíbias sem nódoa amarela basal; esporões mesotibiais castanho-claros; tergos enegrecidos.

Cabeça micro-reticulada; placa labral polida e retangular, sem carenas laterais, somente com angulosidades aos lados; clípeo com pontos grandes e rasos, também micro-reticulados; supraclipeal um pouco elevada em direção à carena frontal, micro-reticulada e sem pontos; carena frontal curta e fina, ultrapassando um pouco os alvéolos; fóveas faciais estreitas e brilhantes, um pouco mais largas dorsalmente, menores que 1/4 do comprimento dos olhos $(0,26: 1,20)$; genas com angulosidade ventral obtusa; mesoscuto e escutelo microreticulados, quase foscos e com os pontos finos esparsos quase igualando o tamanho dos retículos, no escutelo os pontos mais escassos; mesepisternos com micro-reticulação densa; depressão basal do propódeo maior que a metade do comprimento do metanoto, com rúgulas curtas e trabéculas longas até o rebordo posterior formando alvéolos irregulares alongados; tergos com micro-reticulação densa, a faixa marginal larga também micro-reticulada porém brilhante; sexto esterno com o recorte em "U" mais largo junto à base e a carena basal em arco.

Pilosidade branca, menos na face ventral dos basitarsos creme-amarelada, no tergo distal castanho-pálida; do quarto ao sexto tergo com franja rala decumbente subapical.
Holótipo macho. BRASIL. Santa Catarina: "Santa Catarina / Nova Teutonia [Seara] / Brazil [sic] X.1950 / F. Plaumann" (DZUP).

Comentário. O macho distingue-se das espécies com a placa labral e o clípeo amarelos, pela mácula amarela apical do escapo.

\section{Anthrenoides rodrigoi sp. nov.}

(Fig. 16)

Diagnose. Tanto o macho como a fêmea com o mesoscuto e escutelo polidos, o mesoscuto com pontos esparsos no disco e o escutelo com áreas grandes sem pontos. Macho com placa labral, clípeo e paroculares inferiores amarelos; supraclipeal polida e pontuada, genas com tubérculo muito pequeno na angulosidade ventral; área micro-reticulada após a depressão basal do propódeo.

Holótipo macho. Comprimento aproximado 7,84; comprimento da asa 5,10; largura da cabeça 2,30; altura da cabeça 1,70; comprimento do olho 1,25. Tegumento preto na cabeça e mesossoma, porém amarelo na placa labral, clípeo e paroculares inferiores; o clípeo com duas nódoas castanhas muito pequenas e a margem castanho-pálida; máculas paroculares quase até o meio das suturas subantenais externas e mais longas junto às órbitas, terminando abaixo da tangente alveolar inferior. Antenas enegrecidas, porém ventralmente castanho-claras do terceiro flagelômero ao apical; tégulas castanho-escuras, translúcidas; asas tingidas de castanho; tíbias anteriores e medianas com nódoa amarela basal; esporões mesotibiais esbranquiçados; tergos castanho-enegrecidos, fracamente avermelhados, com faixa marginal translúcida da mesma cor, o distal castanho-amarelado; esternos um pouco mais escuros que o tergo distal.

Placa labral curta e trapezoidal, as carenas laterais somente junto ao ápice; clípeo polido, sem carena mediana e com pontos grandes; supraclipeal polida, com pontos mais densos e pouco menores que os do clípeo, sem área discal lisa porém elevada em direção à carena frontal, esta fina e limitada à área interalveolar; fóveas faciais muito curtas e estreitas, alargando um pouco dorsalmente, medindo cerca de $1 / 5$ do comprimento dos olhos $(0,24 ; 1,25)$; genas com angulosidade ventral terminando em um tubérculo muito pequeno; mesoscuto e escutelo polidos, o mesoscuto denso-pontuado em volta e com pontos esparsos no disco; o escutelo com áreas grandes sem pontos; propódeo com a depressão basal tão longa como o metanoto, com rúgulas densas e quase paralelas, o contorno posterior pouco marcado, área polida mediana longa, posteriormente à depressão basal, ladeada por áreas microreticuladas quase foscas; mesepisternos micro-reticulados; tergos basais com pontos finos e densos, a faixa marginal larga e fracamente micro-reticulada; sexto esterno com a carena basal em arco mais estreita medianamente e prolongada em forma de semi-círculo, em direção à base do esterno.

Pilosidade branca, porém fracamente acastanhada no mesoscuto, face ventral dos basitarsos anteriores com pilosidade creme-amarelada, nos medianos e posteriores quase 
branca; no tergo distal os pêlos fracamente acastanhados; tergos com pelinhos esparsos, do primeiro ao quarto com franjas laterais, no quinto e sexto franja rala, longa e decumbente.

Fêmea. Comprimento aproximado 6,60; comprimento da asa 4,88; largura da cabeça 2,30; altura da cabeça 1,71 ; comprimento do olho 1,25 . Tegumento preto menos a face ventral do flagelo, de um castanho-claro a partir do terceiro flagelômero. Tégulas castanhas; asas tingidas de castanho; tíbias anteriores e medianas com nódoa amarela basal; esporões mesotibiais amarelo-acastanhados; tergos com faixa marginal castanho-enegrecida, um pouco mais clara no bordo; esternos com a faixa marginal esbranquiçada e translúcida.

Placa labral quase quadrangular, arredondada nos cantos e com as carenas laterais nos $2 / 3$ distais, sem rúgulas; clípeo polido e sem carena mediana, com pontos grandes e bem marcados; supraclipeal polida e protuberante, sem pontos no disco, pontos grandes nos lados; carena frontal curta e finíssima, tendo ventralmente uma pequena fóvea interalveolar; fóveas faciais estreitas e brilhantes, um pouco mais estreitas embaixo, aproximadamente $1 / 3$ do comprimento dos olhos $(0,40: 1,25)$; mesoscuto polido com os pontos muito esparsos; escutelo polido com duas áreas laterais grandes desprovidas de pontos; depressão basal do propódeo mais curta que o metanoto, com rúgulas paralelas e muito próximas, rebordo posterior pouco elevado; esporões mesotibiais com 5 a 6 espinhos finos; tergos como no macho.

Pilosidade branca exceto na face ventral dos basitarsos, creme-acastanhada, no quinto e sexto tergos castanha; face ventral dos mesepisternos com cerdas finas, eretas e com as pontas dobradas em gancho; curtíssima nos tergos.

Holótipo macho. BRASIL. Paraná: "Brasil, Paraná, Piraquara, / Mananciais da Serra, / $25^{\circ} 30^{\prime}$ s $48^{\circ} 59^{\prime}$ W / 4.XI.2000, G. A. R. Melo" (DZUP). Parátipos com os mesmos dados do holótipo, 5.XI.2002, 1 fêmea e 2 machos; 9.XII.2003, 1 macho e 2 fêmeas; [Ponta Grossa], Parque Estadual de Vila Velha, 23.XI.2002, G. A. R. Melo leg., 1 fêmea; 20.XI.1966, Moure, Graf, Mielke \& Azevedo leg., 1 fêmea; Curitiba, X.1964, S. Laroca leg., 1 macho (DZUP).

Comentário. Como em A. elegantulus sp. nov. e A antonii sp. nov., o macho com placa labral amarela, mesoscuto polido e área mediana polida atrás da depressão basal do propódeo; entretanto em A. rodrigoi, atrás da depressão basal do propódeo ocorrem áreas micro-reticuladas foscas ladeando a área mediana polida; e em $A$. elegantulus e $A$ antonii, a área polida é muito larga e ladeada por áreas brilhantes com microreticulação fraquíssima. A fêmea de $A$. rodrigoi tem o mesoscuto e o escutelo polidos, o escutelo com áreas grandes sem pontos. O parátipo macho de Curitiba tem nódoa amarela nas mandíbulas.

Nome em homenagem ao Rodrigo B. Gonçalves.

\section{Anthrenoides santiagoi sp. nov.}

Diagnose. Fêmea com a placa labral quase quadrada, com rúgulas divergentes do meio para os lados; supraclipeal micro- reticulada; carena frontal fina e longa; basitarsos anteriores e medianos com pêlos castanhos, face dorsal das tíbias posteriores com cerdas brancas.

Holótipo fêmea. Comprimento aproximado 8,58; comprimento da asa 7,02; largura da cabeça 2,54; altura da cabeça 2,01; comprimento do olho 1,48. Tegumento preto, faixa marginal dos tergos e dos esternos amarelo-acastanhada. Asas tingidas de castanho, prestigma acastanhado, pterostigma méleo; tíbias sem nódoa amarela basal; esporões mesotibiais castanhos.

Placa labral quase quadrangular com as carenas laterais nos $2 / 3$ distais, com rúgulas basais divergentes do meio para os lados e uma rúgula mediana; clípeo sem carena, com microreticulação fraca e pontos grandes; supraclipeal microreticulada com pontos rasos, um pouco elevada; carena frontal fina, longa e rasa, até o ocelo mediano; fóveas faciais longas e brilhantes, marcadas por pontos e micro-reticulação irregular, alargando um pouco dorsalmente porém mais estreitas na extremidade dorsal, maiores que $1 / 3$ do comprimento dos olhos $(0,54: 1,48)$; mesoscuto e escutelo brilhantes com microreticulação rasa, os pontos mais densos em volta do mesoscuto e maiores que os retículos; escutelo com pontos maiores que os do mesoscuto, esparsos e separados por espaços maiores e irregulares; esporões mesotibiais tão longos como dois terços dos basitarsos, com 6 espinhos; mesepisternos microreticulados; depressão basal do propódeo tão longa como o metanoto, com micro-reticulação fraca, sem rúgulas; primeiro tergo brilhante, quase sem pontos, segundo e terceiro densamente pontuados.

Pilosidade branca e creme; nas tíbias medianas castanhoenegrecida; basitarsos anteriores e medianos inteiramente castanhos e os posteriores com cerdas de cor creme, ventralmente; branca na face dorsal das tíbias posteriores; face ventral dos mesepisternos com cerdas fracamente onduladas; tergos com pêlos esbranquiçados, curtos e decumbentes, castanho-claros no quinto e nos lados do sexto.

Holótipo fêmea. BRASIL. Paraná: "Brasil, Piraquara / Mananciais da Serra, $25^{\circ}$ S 29' $48^{\circ}$ S 59’ W, / 20.X.2001. G. A. R. Melo" (DZUP). Parátipos. Paraná: Curitiba, X.1962, S. Laroca leg., 1 fêmea; Tijucas do Sul (Vossoroca), 14.IX.1975, Pe. Moure \& Camargo leg., 3 fêmeas (DZUP).

Comentários. As cerdas brancas das tíbias posteriores e a depressão basal do propódeo sem rúgulas separam esta espécie de $A$. cyphomandrae sp. nov. Um dos parátipos de Tijucas do Sul com a cabeça e o metassoma colados em um cartão, o parátipo de Curitiba, com a cabeça colada no cartão.

Em homenagem ao Prof. Dr. Jesus Santiago Moure, Departamento de Zoologia, UFPR.

\section{Anthrenoides serranicola sp. nov.}

(Figs. 17, 31)

Diagnose. Macho sem máculas amarelas na cabeça, supraclipeal protuberante com pontuação densa, depressão basal do propódeo com alvéolos irregulares, mesoscuto sem 
micro-reticulação porém denso-pontuado, mesepisternos foscos, tergos densamente pontuados.

Holótipo macho. Comprimento aproximado 8,93; comprimento da asa 7,40; largura da cabeça 2,53; altura da cabeça 1,99; comprimento do olho 1,40. Tegumento enegrecido, excetuando a placa labral, mandíbulas, clípeo, pernas, metanoto, propódeo e metassoma castanho-enegrecidos, com uma tonalidade avermelhada; asas tingidas de amareloacastanhado; tíbias sem nódoa amarela basal; esporões mesotibiais castanhos; tergos com a faixa marginal castanha; esternos com margem amarelo-acastanhada.

Placa labral trapezoidal, quase tão longa como a largura basal e com emarginação distal pouco marcada, as carenas laterais nos $2 / 3$ distais; clípeo polido, com carena mediana baixa e larga, os pontos grandes separados por espaços do tamanho dos pontos; supraclipeal polida e protuberante, com pontuação densa, os pontos menores que os clipeais; fronte elevada medianamente, com carena baixa interalveolar; fóveas faciais profundas e largas, mais longas que $1 / 3$ do comprimento dos olhos $(0,54: 1,40)$; genas sem angulosidade ventral e mais largas dorsalmente, quando vistas de perfil; mesoscuto polido e denso-pontuado, escutelo polido, com pontos maiores que os do mesoscuto e áreas grandes desprovidas de pontos; mesepisternos foscos, densamente micro-reticulados; depressão basal do propódeo mais curta que a metade do comprimento do metanoto, com rebordo posterior e rúgulas separando alvéolos de tamanhos irregulares; tergos foscos, com micro-reticulação irregular e pontuação densa, faixa marginal larga e micro-reticulada, também fosca; sexto esterno com carenas laterais convergentes, separadas por área muito reduzida.

Pilosidade branca, quase toda danificada no espécime; creme amarelada na face ventral dos basitarsos.

Holótipo macho. BRASIL. Paraná: "Est. [ado] Paraná / Alto da Serra / 13.XI.51 / M. Paranaense"; no verso: "R. Lange leg." (DZUP).

Comentário. Entre os machos com o clípeo enegrecido e paroculares sem mácula amarela, esta espécie chama a atenção pela pontuação densa do clípeo, pela aparência das genas, mais largas dorsalmente e pelos alvéolos na depressão basal do propódeo. O holótipo está estilopizado, com a parte distal do parasita exposta entre o quarto e quinto tergos.

\section{Anthrenoides zanellai sp. nov.}

(Fig. 32)

Diagnose. Macho com o clípeo inteiramente castanhoescuro ou com nódoa subapical amarela; sem máculas amarelas nas paroculares; fóveas faciais muito rasas, fronte com carena fina e longa.

Holótipo macho. Comprimento aproximado 6,70; comprimento da asa 5,32; largura da cabeça 1,95; altura da cabeça 1,52; comprimento do olho 1,03. Cabeça de um castanho-escuro levemente avermelhado; clípeo com pequena nódoa amarela triangular subapical; antenas com os quatro flagelômeros basais enegrecidos dorsalmente e na face ventral somente os dois basais pretos e os restantes de um castanhoocráceo; mesoscuto, escutelo e metanoto pretos, restante do mesossoma e as pernas de um castanho-escuro um pouco avermelhado; asas tingidas de castanho; tíbias sem nódoa amarela basal; esporões mesotibiais esbranquiçados; tergo basal castanho com área amarelo-acastanhada subapical, os demais tergos e os esternos pretos com áreas castanhas dispersas e a faixa marginal amarelo-acastanhada.

Placa labral semi-circular, com carenas laterais junto ao ápice; clípeo micro-reticulado com os pontos também microreticulados e esparsos; supraclipeal um pouco elevada em direção ao meio da fronte, micro-reticulada e quase sem pontos; fronte com carena fina e longa, finíssima dorsalmente; fóveas faciais muito rasas, menores que $1 / 3$ do comprimento dos olhos (0,28: 1,03); genas com angulosidade ventral obtusa; mesoscuto e escutelo brilhantes com micro-reticulação fraquíssima, os pontos não densos separados por espaços variáveis, mais esparsos no escutelo; depressão basal do propódeo tão longa como o metanoto, com rúgulas muito curtas esparsas; segundo tergo com pontos finos pouco densos, no basal e nos distais os pontos muito escassos, a faixa marginal larga e brilhante um pouco marcada por microreticulação; sexto esterno com carena basal em arco, contínua com as margens laterais do mesmo.

Pilosidade branca predominando, amarelo-âmbar na face ventral dos tarsômeros; lados do segundo ao quarto tergo com pêlos alongados, no quinto e sexto tergos com franja rala de pêlos longos, esparsos e decumbentes na faixa marginal.

Holótipo macho. BRASIL. Paraná: “Curitiba / 27-9-55”, [sem indicação do coletor], (DZUP). Parátipos. Da mesma localidade, Barigüi [bairro], X.1940, Pe. J. S. Moure leg., 1 macho; São José dos Pinhais, 9-16.VII.1984, CIIF (malaise), 3 machos; com os mesmos dados 18.X.1984, 1 macho; da mesma localidade, BR 277, km 53,5, Torre da Telepar, 16-20.VII.1994, J. A. Rafael leg., (malaise), 1 macho; Paranaguá, BR 277 km 32, 2-9.VII.1984, CIIF (malaise), 2 machos; Morretes, (IAPAR), 17-24.IX.1984, CIIF (malaise), 2 machos; mesmos dados, 8-15.X.1984, 1 macho (DZUP).

Comentário. Como em A. guttulatus com o clípeo castanho escuro com mácula amarela subapical pouco conspícua e sem máculas paroculares amarelas. O parátipo de Curitiba com algumas rúgulas longas nos lados da depressão propodeal e sem área amarela no clípeo. A maioria dos machos com o clípeo uniformemente castanho-enegrecido ou preto, entretanto os parátipos de Paranaguá com mácula amarela subapical no clípeo, em um deles com a forma de pequena faixa amarela na parte mediana e outro com mácula obscura amarelada; o parátipo de Morretes com mácula amarela clipeal triangular.

Dedicada ao Prof. Dr. Fernando César Vieira Zanella, Departamento de Engenharia Florestal, UFCG, Campina Grande, Paraíba.

Para estabelecer comparações com as espécies novas, são apresentados a seguir os caracteres principais de Anthrenoides 
meridionalis (Schrottky, 1906) e de Anthrenoides micans Urban, 1995.

\section{Anthrenoides meridionalis (Schrottky, 1906)}

(Fig. 18)

Protandrena meridionalis Schrottky, 1906: 314

Anthrenoides alfkeni Ducke, 1907: 368. - Ducke, 1908: 65 (syn.).

Panurginus saltensis var. nigroclypeata Friese, 1908: 27. - Schlindwein \& Moure, 1999: 129 (syn.)

Panurginus flaviceps Friese, 1916: 171. - Schlindwein \& Moure, 1999: 129 (syn.).

Anthrenoides cf. meridionalis; Camargo \& Mazucato, 1984: 63.

Anthrenoides meridionalis; Wittmann \& Hoffmann, 1990: 20.

Macho com placa labral preta, o clípeo e as máculas paroculares amarelos, o clípeo com duas nódoas junto às fóveas tentoriais e a margem enegrecidas; a mácula parocular em forma de gota, até o terço inferior da sutura subantenal externa; tíbias anteriores e medianas com nódoa amarela basal.

Placa labral semi-circular com as carenas laterais até o meio; clípeo polido com pontos grandes esparsos; supraclipeal polida, protuberante e quase sem pontos no disco, pontuada aos lados e com pequena fóvea mediana alongada; fronte sem carena; fóveas faciais estreitas e curtas, menores que $1 / 4$ do comprimento do olho $(0,23: 1,04)$; genas com angulosidade obtusa ventral; mesoscuto e escutelo polidos; o mesoscuto com áreas fracamente micro-reticuladas, pontuação irregular no disco deixando espaços de 1 a 4 diâmetros de ponto, escutelo com espaços maiores sem pontos; mesepisternos microreticulados; depressão basal do propódeo mais longa que o metanoto, com rúgulas anastomosadas irregularmente; tergos brilhantes com pontuação densa na metade basal do segundo e terceiro, muito esparsa no restante do terceiro e nos demais tergos, a faixa marginal brilhante e sem micro-reticulação. Sexto esterno com as carena subapical em arco. Pilosidade esbranquiçada.

Fêmea com o tegumento enegrecido; tíbias anteriores e medianas com nódoa amarela basal.

Placa labral com os bordos retos na metade basal e arredondados na distal, carenas laterais nos $2 / 3$ distais, com rúgulas basais fracas; clípeo, supraclipeal e fronte como no macho; na supraclipeal com um ponto médio-apical pouco maior que os adjacentes; fóveas faciais estreitas, um pouco alargadas para o meio, pouco maiores que $1 / 3$ do comprimento dos olhos $(0,48: 1,25)$; mesoscuto micro-reticulado com pontos separados por espaços variando de 2 a 4 diâmetros de ponto; escutelo polido com pequenas áreas micro-reticuladas e pontos esparsos; esporões mesotibiais medindo cerca de $2 / 3$ do comprimento dos basitarsos, com 6 espinhos finos, serrilhado para a base; depressão basal do propódeo como no macho.

Pilosidade predominante branca, lado externo das tíbias posteriores com cerdas castanhas na base e esbranquiçadas na ponta; área ventral dos mesepisternos com cerdas finas dobradas nas pontas.
Material examinado (DZUP). BRASIL. Minas Gerais: Barbacena, Poços de Caldas Morro do Ferro, Araponga e Itajuba; Rio de Janeiro: Itatiaia 2200m, Retiro Pedro do Rio; São Paulo: Campos do Jordão, Barueri, Serra da Bocaina 1500m; S. José do Barreiro; Paraná: Curitiba, Fênix, Tijucas do Sul, São José dos Pinhais; Santa Catarina: Seara, Nova Teutônia; Rio Grande do Sul: Barão de Cotegipe.DUCKE (1908) citou do Ceará: Serra de Baturité.

Um dos síntipos de Protandrena meridionalis encontrase na Coleção de Entomologia do Instituto Oswaldo Cruz (IOC), Rio de Janeiro, segundo Ferraz (1997), de Villa Encarnación, Paraguay, (no. 10) coletado por C. Schrottky, sem a data da coleta, que a autora interpretou como holótipo, ao descrever a espécie, Schrottky (1906) registrou 4 machos.

O lectótipo de Anthrenoides alfkeni Ducke, 1907, designado por Nascimento (1979), sem a indicação do sexo, está no Museu Paraense Emílio Goeldi, Belém-PA. Foi examinado um paralectótipo macho de $A$. alfkeni, coletado em Barbacena, Minas Gerais, com a cabeça e o mesossoma em boas condições, porém sem o metassoma, no DZUP.

Comentário. Dentre os machos com máculas amarelas na cabeça, placa labral enegrecida e o clípeo polido, $A$. meridionalis se distingue de $A$. araucariae sp. nov., $A$. meloi sp. nov e A. larocai sp. nov., pela ausência de carena frontal e pelas fóveas faciais curtas, tão estreitas como a metade do diâmetro do ocelo. Em A. araucariae as fóveas faciais são largas e longas, tão largas como o ocelo; em $A$. meloi e $A$. larocai as fóveas faciais são alargadas na metade dorsal. A fêmea de A. meridionalis se distingue pela supraclipeal polida e sem pontos no disco e depressão basal do propódeo mais longa que o metanoto, além das fóveas faciais estreitadas nas pontas e das cerdas bicoloridas das tíbias posteriores.

\section{Anthrenoides micans Urban, 1995.}

(Fig. 25)

Anthrenoides micans Urban, 1995: 403.

Os caracteres relacionados a seguir complementam a descrição da espécie.

Macho. Nódoa amarela basal nas tíbias anteriores e medianas, nas posteriores a placa basititbial também amarela. Placa labral amarela, curta e com a margem arredondada, as carenas laterais quase até a base, com rúgulas pequenas no ápice; clípeo polido um pouco marcado por micro-reticulação, com pontos distribuídos irregularmente e bem marcados; supraclipeal polida, elevada em carena baixa mediana, densamente pontuada; fronte com carena fina ultrapassando a área supraclipeal; fóveas faciais estreitas e brilhantes medindo quase $1 / 6$ do comprimento do olho $(0,19: 1,30)$; genas obtusas ventralmente; mesoscuto com micro-reticulação rasa e pontuação densa; escutelo polido, com pontuação densa; mesepisternos micro-reticulados; depressão basal do propódeo mais longa que a metade do metanoto, muito curta nos lados, com rúgulas irregulares anastomosadas no meio e muito curtas nos flancos; rebordo posterior elevado; tergos 
micro-reticulados com a faixa marginal quase fosca, os dois tergos basais com pontuação densa, um pouco mais esparsa no terceiro; sexto esterno com o recorte mediano esteitando muito para a base, onde iguala o diâmetro do ocelo, com carena basal em arco, contínua com as margens laterais.

Fêmea com nódoa amarela na base das tíbias anteriores e medianas; placa labral retangular alargada, com as carenas laterais quase até a articulação labro-clipeal, sem rúgulas basais; clípeo polido com pontos grandes e profundos como no macho; supraclipeal elevada em direção à fronte, polida, com pontuação densa e áreas lisas irregulares quase iguais ao tamanho dos pontos junto à elevação frontal; fronte elevada $\mathrm{e}$ sem carena distinta; fóveas faciais um pouco estreitadas nas pontas e muito largas pouco acima do meio, medindo quase $1 / 4$ do comprimento do olho $(0,38: 1,60)$; esporões mesotibiais castanhos, com 4 espinhos muito finos; face externa das tíbias posteriores com cerdas brancas; estruturas do mesossoma e tergos como no macho.

Material-tipo. Holótipo macho e parátipos machos e fêmeas do Brasil, Rio Grande do Sul: Santana da Boa Vista e Caçapava do Sul (DZUP).

Comentário. O macho distingue-se dos demais com placa labral amarela e mesepisternos micro-reticulados, por ter mácula amarela na base do escapo e o recorte do sexto esterno muito estreito basalmente; o macho de $A$. reticulatus sp. nov. tem mácula amarela no ápice do escapo e o recorte em "U" do sexto esterno largo na base. A fêmea assemelha-se à de $A$. petuniae sp. nov.

Chave para as espécies de Anthrenoides Machos

1. Glossa extremamente longa medindo aproximadamente quatro vezes o comprimento das gáleas; clípeo protuberante, em vista de perfil mais largo que as genas; tergos com faixa marginal larga opaca, amarelada ................................ admirabilis sp. nov.

Glossa curta ou alongada porém não ultrapassando o dobro do comprimento das gáleas; clípeo quase plano ou pouco protuberante, mais estreito que as genas em vista de perfil; tergos com faixa marginal castanha ou enegrecida, quando amarelada quase transparente ... 2

2(1). Clípeo inteiramente enegrecido ou em grande parte castanho com áreas amarelas ..... 3

Clípeo predominantemente amarelo ou esbranquiçado, com nódoas pequenas enegrecidas perto das fóveas tentoriais ou máculas discais castanhas irregulares mais longas que o dobro do ocelo mediano, a margem enegrecida 7

3(2). Paroculares inferiores com mácula amarela; clípeo castanho, contornado irregularmente com amarelo e com estria mediana amarela ....... A. magaliae sp. nov.
Paroculares inferiores sem mácula amarela, inteiramente enegrecidas; clípeo enegrecido ou com nódoa subapical amarela obsoleta ......................................... 4

4(3). Placa labral trapezoidal alongada, com o ápice emarginado; depressão basal do propódeo mais curta que a metade do comprimento do metanoto, com alvéolos separados por trabéculas .

A. serranicola sp. nov.

Placa labral curta e arredondada; depressão basal do propódeo mais longa que a metade do comprimento do metanoto, quase lisa 5

5(4). Com fóvea interalveolar alongada em forma de gota, unida dorsalmente à carena frontal, a fóvea mais longa que o diâmetro do ocelo mediano; depressão basal do propódeo pouco mais longa que a metade do comprimento do metanoto .. A. guttulatus $\mathbf{s p . ~ n o v}$

Sem fóvea interalveolar mediana junto à carena frontal; depressão basal do propódeo igual ou mais longa que o metanoto

6(5). Genas sem tubérculo na angulosidade ventral; clípeo micro-reticulado com projeções látero-apicais curtas e em forma de lóbulos . A. zanellai sp. nov.

Genas com tubérculo ventral com formato piramidal; clípeo polido com projeções látero-apicais digitiformes A. ornatus sp. nov.

7 (2). Placa labral amarela ou esbranquiçada ......................... 8

Placa labral preta ou castanha ....................................... 15

8(7). Clípeo e máculas paroculares esbranquiçados .......... 9

Clípeo e máculas paroculares amarelos ....................... 10

9(8). Mesepisternos polidos ....................... A. antonii sp. nov. Mesepisternos micro-reticulados

A. elegantulus sp. nov.

10 (8). Escapo com mácula amarela apical; depressão basal do propódeo com trabéculas formando alvéolos alongados um pouco irregulares

A. reticulatus sp. nov.

Escapo sem mácula amarela apical; depressão basal do propódeo sem alvéolos alongados, lisa ou com rúgulas 11

11(10). Sexto esterno com o recorte mediano mais próximo de um "V" mais largo distalmente e na base igualando o diâmetro do ocelo; escapo com nódoa amarela basal A. micans Urban, 1995

Sexto esterno com o recorte mediano em "U" tão largo na base como na parte distal; escapo enegrecido, sem nódoa amarela basal .12

12(11). Genas com a angulosidade ventral projetada para trás em forma de tubérculo; depressão basal do propódeo 
com rebordo posterior pouco marcado, porém com área mediana polida, mais larga que o diâmetro do ocelo A. rodrigoi sp. nov.

Genas sem tubérculo na angulosidade ventral; depressão basal do propódeo com rebordo posterior elevado e carenado, no restante micro-reticulado, sem área mediana polida 13

13(12). Quinto esterno com carena subapical em ângulo obtuso; sexto esterno com as carenas laterais convergentes na base, separadas por pequena área A. larocai sp. nov.

Quinto esterno sem carena subapical; sexto esterno com carena basal contínua, em forma de arco ...... 14

14(13). Mesoscuto e escutelo polidos ....... A. petuniae sp. nov. Mesoscuto e escutelo micro-reticulados A. palmeirae sp. nov.

15(7). Máculas paroculares e clípeo esbranquiçados ........ 16 Máculas paroculares e clípeo amarelos 18

16(15). Genas com lóbulo ventral arredondado, achatado e carenado, projetado para trás; clípeo inteiramente micro-reticulado; sexto esterno com duas carenas basais convergentes, não unidas

A. faviziae sp. nov.

Genas fracamente angulosas ventralmente ou com tubérculo pequeno não carenado; clípeo polido com pequenas áreas basais micro-reticuladas; sexto esterno com carena basal contínua, reta ou em arco

17(16). Genas fracamente angulosas ventralmente; paroculares infladas medialmente ........... A. guarapuavae sp. nov.

Genas com tubérculo pequeno não carenado; paroculares deprimidas medialmente, não elevadas A. pinhalensis sp. nov.

18(15). Fóveas faciais em forma de gota, dorsalmente tão largas como o dobro da largura da parte ventral 19

Fóveas faciais elipsóides ou um pouco alargadas no meio, raramente com pequeno alargamento dorsal

19(18). Fronte com sulco pontilhado entre duas carenas finas e longas, quase até o ocelo mediano; quinto esterno sem carena subapical; sexto esterno com carena basal reta A. meloi sp. nov.

Fronte com elevação mediana larga e curtíssima; quinto esterno com carena subapical fina e curta; sexto esterno com carenas basais convergentes

A. larocai sp. nov.

20(18). Mesepisternos polidos com pequena área microreticulada dorsal; três artículos distais dos palpos labiais longos, maiores que o dobro do diâmetro do ocelo A. araucariae sp. nov.

Mesepisternos inteiramente micro-reticulados; três artículos distais dos palpos labiais pouco mais longos que o diâmetro do ocelo mediano 21

21(20).Clípeo e área supraclipeal micro-reticulados, foscos; mesoscuto micro-reticulado ........... A. paolae sp. nov.

Clípeo e área supraclipeal polidos, brilhantes; mesoscuto polido 22

22(21). Clípeo com duas projeções digitiformes laterais e máculas discais castanhas mais longas que o dobro do ocelo mediano A. albinoi sp. nov.

Clípeo com projeções látero-apicais lobuladas e pequenas nódoas enegrecidas próximas das fóveas tentoriais A. meridionalis (Schrottky, 1906)

Fêmeas

1. Glossa extremamente longa, quase igualando o comprimento do corpo; clípeo protuberante, em vista de perfil mais largo que as genas; tergos com faixa marginal larga opaca e amarelada

A. admirabilis sp. nov.

Glossa não ultrapassando o dobro do comprimento da gálea; clípeo pouco elevado ou protuberante, mais estreito que as genas em vista de perfil; tergos sem faixa marginal larga fosca e esbranquiçada 2

2(1). Clípeo polido e com carena mediana conspícua; fóveas faciais em forma de gota, dorsalmente mais largas que o dobro da largura ventral ........ A. meloi sp. nov. Clípeo polido e sem carena mediana, ou micro-reticulado e variável quanto à carena mediana; fóveas faciais elipsóides ou um pouco mais largas no meio porém não atingindo o dobro da largura da parte ventral . 3

3(2). Placa labral com área semi-circular com rúgulas anastomosadas junto à articulação labro-clipeal e numerosas rúgulas divergentes quase até o ápice; cabeça alongada, a altura pouco menor que a largura $(2,10: 2,32)$..................................... A. larocai sp. nov.

Placa labral lisa ou com rúgulas divergentes, sem área semi-circular com rúgulas anastomosadas; cabeça larga, a altura aproximadamente $3 / 4$ da sua largura ... 4

4(3). Clípeo polido, às vezes com pequenas áreas basais micro-reticuladas; supraclipeal geralmente polida .5

Clípeo micro-reticulado ou micro-esculturado, por inteiro ou na metade basal; supraclipeal microreticulada, ou com pequena área discal polida .... 13

5(4). Mesepisternos polidos, com micro-reticulação fraquíssima em pequenas áreas; depressão basal do propódeo brilhante e sem rúgulas

A. antonii sp. nov. 
Mesepisternos micro-reticulados; depressão basal do propódeo com rúgulas paralelas ou anastomosadas

6(5). Depressão basal do propódeo curta, aproximadamente a metade do comprimento do metanoto .................... 7

Depressão basal do propódeo quase igualando ou ulrapassando o comprimento do metanoto .............. 9

7(6). Mesepisternos com pontuação densa e bem marcada, os pontos como os do mesoscuto, maiores que 3 a 4 retículos; mesoscuto com pontuação extremamente densa, pontos separados pelas cristas ou por pequena área lisa A. albinoi sp. nov.

Mesepisternos com pontuação fina e superficial, os pontos muito esparsos e pouco maiores que os retículos; mesoscuto com pontuação variável porém os espaços entre os pontos maiores que 1 diâmetro de ponto ... 8

8(7). Supraclipeal denso-pontuada, no disco os pontos mais afastados com os intervalos igualando o dobro do tamanho dos pontos; fóveas faciais menores que um terço do comprimento do olho, com angulosidade obtusa na margem medial

A. micans Urban, 1995

Supraclipeal denso-pontuada somente junto ás suturas subantenais internas, sem pontos no disco; fóveas faciais distintamente mais longas que um terço do comprimento do olho, margem medial em arco muito fraco A. petuniae sp. nov.

9(6). Face ventral dos mesepisternos com cerdas finas não dobradas na ponta; palpos labiais com os três artículos distais tão longos como o dobro do diâmetro do ocelo médio ......... A. corrugatus sp. nov.

Face ventral dos mesepisternos com cerdas finas com as pontas dobradas; palpos labiais com os três artículos distais um pouco mais longos que o diâmetro do ocelo médio 10

10 (9). Mesoscuto polido, os pontos separados por áreas lisas grandes A. rodrigoi sp. nov. Mesoscuto micro-reticulado brilhante 11

11(10). Tergos amarelo-âmbar ou arruivados ou em grande parte desta cor; clípeo polido com área basal microreticulada; supraclipeal micro-reticulada e brilhante; tergo basal com pontos finíssimos muito esparsos A. pinhalensis sp. nov.

Tergos pretos ou enegrecidos; clípeo inteiramente polido; supraclipeal polida; tergo basal com pontuação fina e densa no disco 12

12(11). Carena frontal curta e fina; depressão basal do propódeo mais curta que o metanoto, com numerosas rúgulas paralelas; tíbias posteriores com cerdas brancas na face dorsal ..... A. politus sp. nov.

Sem carena frontal; depressão basal do propódeo mais longa que o metanoto, com rugosidades superficiais anastomosadas; face dorsal das tíbias posteriores com cerdas bicoloridas, castanho-enegrecidas na base e brancas na ponta A. meridionalis

13(4). Fóveas faciais curtas, medindo $1 / 4$ do comprimento do olho ou mais curtas .14

Fóveas faciais longas, aproximadamente $1 / 3$ do comprimento do olho 15

14(13). Mesoscuto brilhante com micro-reticulação extremamente superficial, pontuação densa, os pontos maiores que os retículos; três tergos basais com pontuação densa e a faixa marginal com microreticulação densa, quase fosca; supraclipeal microreticulada em parte. A. palmeirae sp. nov.

Mesoscuto micro-reticulado, quase fosco, com pontuação esparsa, os pontos quase igualando os retículos; três tergos basais esparsamente pontuados, faixa marginal brilhante com microreticulação fraca, pouco distinta; supraclipeal inteiramente micro-reticulada

A. paranaensis sp. nov.

15(13). Mesoscuto com pontuação extremamente densa, os pontos separados somente pelas cristas que os contornam .. 16

Mesoscuto com pontuação variável, os espaços entre os pontos, no disco, maiores que dois diâmetros de ponto . 17

16(15). Esporões mesotibiais com espinhos nos $2 / 3$ distais; clípeo com carena mediana fina e área apical microreticulada; tíbias posteriores com cerdas castanhas mescladas com cerdas bicoloridas, castanhas na base e brancas na ponta

A. densopunctatus sp. nov.

Esporões mesotibiais sem espinhos; clípeo sem carena mediana e com área apical polida entre os pontos; tibias posteriores com cerdas brancas

A. langei sp. nov.

17(15). Escutelo brilhante, polido ou com micro-reticulação muito fraca, os pontos distintamente maiores que os do mesoscuto 18

Escutelo micro-reticulado e fosco, com pontos como os do mesoscuto ou ligeiramente maiores

18(17). Depressão basal do propódeo com rúgulas paralelas; os três artículos distais dos palpos labiais longos como uma vez e meia o diâmetro do ocelo mediano; carena frontal com sulco mediano

A. cyphomandrae sp. nov.

Depressão basal do propódeo micro-reticulada e sem rúgulas; três artículos distais dos palpos labiais 
igualando o diâmetro do ocelo mediano; carena frontal fina, sem sulco mediano

A. santiagoi $\mathbf{s p . ~ n o v . ~}$

19(17). Tíbias posteriores com cerdas brancas na face dorsal; dois artículos distais dos palpos labiais muito curtos quase igualando a metade do diâmetro do ocelo médio A. paolae sp. nov.

Tíbias posteriores com cerdas bicoloridas na face dorsal, castanhas na base e brancas na ponta; dois artículos distais dos palpos labiais longos como o diâmetro do ocelo médio A. ornatus sp. nov.

Na chave para a identificação, constam macho e fêmea das seguintes espécies: A. admirabilis, A. albinoi, A. antonii, A. larocai, A. meloi, A. meridionalis, A. micans, A. ornatus, $A$. palmeirae, A. paolae, A petuniae, A pinhalensis e $A$. rodrigoi; somente o macho de $A$. araucariae, $A$. elegantulus, $A$. faviziae, A. guarapuavae, A. guttulatus, A. magaliae, A. reticulatus, A. serranicola e $A$. zanellai; somente a fêmea de $A$. corrugatus, A. cyphomandrae, A. densopunctatus, A. langei, A. paranaensis, $A$. politus e $A$. santiagoi. Novas coletas poderão completar o conhecimento das espécies, possivelmente algumas serão sinonimizadas. O macho de $A$. larocai aparece duas vêzes na chave pelo colorido da placa labral.

Agradecimentos. Ao Prof. Albino Morimasa Sakakibara pelas fotos que ilustram o trabalho; aos coletores do material estudado e ao Prof. Rudolf Bruno Lange pela doação de espécimes.

\section{REFERÊNCIAS}

Camargo, J. M. F. de \& M. Mazucato. 1984. Inventário da apifauna e flora apícola de Ribeirão Preto, SP, Brasil. Dusenia 14: 55-87.

Ducke, A. 1907. Beitrag zur Kenntnis der Solitärbienen Brasiliens. (Hym.). Zeitschrift für systematische Hymenopterologie und Dipterologie VII: 361-368.

Ducke, A. 1908. Contribution à la connaissance de la Faune hyménoptérologique Du Nord-Est du Brésil (1). Revue D'Entomologie 27: 57-81.

Ferraz, M. V. 1997. The Type specimens of Apoidea (Hymenoptera) Deposited in the Entomological Collection of the Instituto Oswaldo Cruz, Rio de Janeiro, RJ, Brazil. Memórias do Instituto Oswaldo Cruz 92: 353-356.

Friese, H. 1908. Die Apiden (Blumenwespen) von Argentina, nach den Reisenergebnissen der Herren A. C. Jensen-Haarup und P. Jöergensen in den Jahren 1904-1907. Flora og Fauna, Silkeborg, 10: 1-94.

Friese, H. 1916. Neue Bienen-Arten aus Chile und Südamerika. (Gatt. Camptopoeum, Psaenythia und Panurginus Hym.). Stettiner Entomologische Zeitung 77: 163-174 [1917].

Michener, C. D. 2000. The Bees of the World. Baltimore \& London, The John Hopkins University Press, xvi $+913 p$.

Nascimento, P. T. R. 1979. Catálogo de tipos entomológicos do Museu Goeldi. Hymenoptera. Boletim do Museu Paraense Emílio Goeldi, Zoologia, 98: 1-18.

Schlindwein, C. \& J. S. Moure, 1999. Espécies de Panurgillus Schlindwein \& Moure (Hymenoptera, Andrenidae) depositados no Naturkunde Museum, Berlin. Revista Brasileira de Zoologia 16: 113-133.

Schrottky, C. 1906. Neue und wenig bekannte südamerikanische Bienen. Zeitschrift für systematische Hymenopterologie und Dipterologie VI: 305-316.

Silveira, F. A.; G. A. R. Melo \& E. A. B. Almeida, 2002. Abelhas Brasileiras Sistemática e Identificação. Belo Horizonte. F. A. Silveira (ed.) 253 p.

Urban, D. 1995. Espécies novas de Paracolletini e Panurginae do sul do Brasil e Argentina (Hymenoptera, Apoidea). Revista Brasileira de Zoologia 12: 397-405.

Wittmann, D. \& M. Hoffmann, 1990. Bees of Rio Grande do Sul, southern Brazil (Insecta, Hymenoptera, Apoidea). Iheringia: 17 43 .

Recebido em 14.VII.2004; aceito em 05.IX.2004 